\title{
Crop rotation complexity regulates the decomposition of high and low quality residues
}

McDaniel $^{1 *}$, M.D., Grandy ${ }^{1}$, A.S., Tiemann ${ }^{1}$, L.K., and M.N. Weintraub ${ }^{2}$

1. Department of Natural Resources and the Environment, University of New Hampshire, Durham, NH USA

2. Department of Environmental Sciences, University of Toledo, Toledo, OH USA

*Corresponding Author:

Present address:

Department of Environmental Sciences

University of Sydney

Centre for Carbon Water and Food

380 Werombi Rd.

Camden, NSW 2570 Australia

Phone: +61029351 1835

Email: marshall.mcdaniel@sydney.edu.au 


\begin{abstract}
While many ecosystem processes depend on biodiversity, the relationships between agricultural plant diversity and soil carbon (C) and nitrogen $(\mathrm{N})$ dynamics remains controversial. Our objective was to examine how temporal plant diversity (i.e. crop rotation) influences residue decomposition, a key ecosystem function that regulates nutrient cycling, greenhouse gas emissions, and soil organic matter formation. We incubated soils from five long-term crop rotations, located at W.K. Kellogg Biological Station LTER in southwestern Michigan, USA, with and without four chemically diverse crop residues. Increasing crop biodiversity increased soil potentially mineralizable $\mathrm{C}$ by $125 \%$, increased hydrolytic enzyme activity by $46 \%$, but decreased oxidative enzyme activity by $20 \%$ in soils before residue was added. After residue additions, soils from more diverse cropping systems decomposed all residues more rapidly (0.28.3\% greater mass loss) compared to monoculture corn. The fast-cycling, 'Active C' pool and microbial biomass $\mathrm{N}$ increased with higher cropping diversity, but the differences among rotations in Active $\mathrm{C}$ pools was higher for the most recalcitrant residues. Further, the ratio of the cellulose degrading enzyme ( $\beta$-glucosidase) to the lignin degrading enzyme (phenol oxidase) was highest in the two most diverse crop rotations regardless of residue additions, providing additional evidence of enhanced microbial activity and substrate acquisition in more diverse rotations. Our study shows that crop diversity over time influences the processing of newlyadded residues, microbial dynamics, and nutrient cycling. Diversifying crop rotations has the potential to enhance soil ecosystem functions and is critical to maintaining soil services in agricultural systems.
\end{abstract}


Keywords: biodiversity; carbon mineralization; extracellular enzymes; litter quality; microbial biomass; nitrogen mineralization

\section{Introduction}

Decades of research shows that the loss of aboveground biodiversity and associated ecosystem functions and services is one of humanity's major challenges (Cardinale et al., 2012; Hooper et al., 2012;Tilman et al., 1997). However, few studies link plant biodiversity to belowground communities and ecosystem processes, limiting our capacity to predict whether future changes in plant communities will influence decomposition and other critical belowground functions. Given that soils sequester carbon (C), store water, support crop growth, and provide other services to our growing population, we have an imperative to better understand the relationships between plant biodiversity and soil processes.

We know that plant species richness may influence soil $\mathrm{C}$ accrual, nutrient cycling, and microbial biomass dynamics, but specific relationships vary across sites and systems (Eisenhauer et al., 2010; Mueller et al., 2013; Zak et al., 2003). For example, Zak et al. (2003) found that increasing species richness from 1 to 16 species in a Minnesota grassland increased soil microbial biomass, nitrogen $(\mathrm{N})$ mineralization, and respiration per-unit-biomass after 7 years. However, they found no effect of plant species richness on bulk soil C or N, and other studies have shown inconsistent effects of plant diversity belowground. Eisenhauer et al. (2010) found that soil microbial biomass, but not respiration rate, was greater with increasing plant species richness. Soil inorganic $\mathrm{N}$ has shown both decreasing (Mueller et al., 2013) and increasing 
(Oelmann et al., 2007) relationships with plant richness. These divergent responses come as no surprise to soil scientists, who have been wrestling for more than a century with soils' staggering biological diversity (Caporaso et al., 2011; Fierer et al., 2007), complex physical structure (Grandy and Robertson 2007, Tiemann and Grandy 2014), and dynamic organic matter chemistry (Heckman et al., 2013), all of which confound predictions of aboveground biodiversity effects on soil function across time and space.

Converting complex natural communities to highly simplified agricultural systems is driving global declines in biodiversity (Heywood, 1995; Sala et al., 2000; Tilman et al., 2001). In agroecosystems, successive, single crop plantings (i.e. crop rotations) create temporal rather than spatial biodiversity. In many industrialized regions, this temporal diversity consists of rotating two crops in two years (e.g. corn-soybean), although both monocultures and longer rotations are not uncommon. Rotational diversity may be further augmented by planting cover crops. Cover crops are not harvested for economic gain but are instead grown to increase soil N, decrease erosion, and increase soil $\mathrm{C}$ inputs. Thus, rotations with and without cover crops are used to increase plant species richness, primarily by substituting temporal for spatial diversity. This "temporal biodiversity" makes agroecosystems a unique and tractable testing ground for examining the effects of plant biodiversity on soils.

Although the mechanisms are unclear, increased temporal plant biodiversity may provide some of the same belowground benefits as spatial diversity. These benefits include increased soil N availability (Drinkwater et al., 1998; Sanchez et al., 2001; Tonitto et al., 2006), increased soil organic matter (SOM) concentrations (Grandy and Robertson, 2007; Kou et al., 2012; Mitchell and Entry, 1998), increased soil microbial biomass (Ekenler and Tabatabai, 2002; McDaniel et al., 2014) and increased soil microbial diversity (Lupwayi et al., 1998; Suzuki et al., 
2012; Xuan et al., 2012). However, despite this evidence of crop rotation's benefits, their centuries of use in agriculture (Bullock, 1992), and current prevalence in U.S. cropping systems (82\% of current agricultural land; Padgitt et al., 2000), little is known about the mechanisms by which crop rotations affect soil biogeochemical processes.

Increasing the diversity of plant inputs to SOM with crop rotation may increase microbial community size, functioning, and biodiversity by creating more habitable resource niches (Hättenschwiler et al., 2005; Zak et al., 2003). Viewed in light of new concepts emphasizing microbial biomass as the key to SOM formation (Grandy and Neff, 2008; Liang and Balser, 2010; Simpson et al., 2007), such increases may be more likely to retain residue C in SOM. Furthermore, residue cometabolism with SOM, and conversion of that residue to SOM (Kuzyakov, 2010; Paterson et al., 2009), may be influenced by long-term rotation effects on soil decomposer communities and SOM. Ultimately, the strong linkage between aboveground biodiversity and soil functioning in crop rotations lies in the quantity, quality, and temporal diversity of crop inputs to soil, because at any one time the spatial plant richness is one.

The general objective of this study was to examine how crop rotational diversity alters the decomposition dynamics of newly-added residue inputs. More specifically, we used crop residues varying in quality to determine how crop rotation history influences $\mathrm{C}$ and $\mathrm{N}$ cycling and soil microbial communities. In a year-long laboratory incubation, we examined the decomposition of four crop residues (Red clover, Triticum aestivum; Soy, Glycine max; Corn, Zea maize; and Wheat, Trifolium pretense) in agricultural soils managed for over a decade with five different corn-based crop rotations. Combining rotations varying in diversity from one to five crops over a three-year period with different litter combinations allows us to test the longerterm rotation effects on processing of newly-added crop residues. Our specific research 
objectives were three-fold: first, we tested variations in potentially mineralizable soil and residue $\mathrm{C}$ pools among rotations by modeling respiration rates determined at 30 time points over a 360 day laboratory incubation; second, we examined soil inorganic $\mathrm{N}$ produced at 3 time points along the 360 day incubation; and third, we measured microbial biomass $\mathrm{C}$ and $\mathrm{N}$ (proxies for biological stimulation, short-term $\mathrm{C}$ and nutrient processing) and soil enzyme activities (proxies for microbial $\mathrm{C}$ and nutrient demand) to understand the microbial regulation of $\mathrm{C}$ and $\mathrm{N}$ cycling in response to residue and cropping system diversity. We predicted that increased crop diversity would enhance soil biogeochemical cycling in general, but especially for poor-quality residues where there may be resource constraints and/or biochemical obstacles (e.g. high lignin) to decomposition.

\section{Methods and Materials}

\subsection{Site and Experiment Description}

Soils for this incubation experiment were collected from the Cropping Biodiversity Gradient Experiment (CBGE) located at the W.K. Kellogg Biological Station (KBS) Long-term Ecological Research site. Mean annual temperature and precipitation at the site are $9.7^{\circ} \mathrm{C}$ and $890 \mathrm{~mm}$, respectively. The two main soil series found at the site are Kalamazoo, a fine-loamy, mixed, mesic Typic Hapludalf, and Oshtemo, a coarse-loamy, mixed, mesic Typic Hapludalf (KBS, 2013). The CBGE crop rotation experiment was initiated in 2000, with biodiversity increased through the systematic addition of crops in rotations ranging from single crop monocultures to complex rotations with three different grain crops and two cover crops for a total of five species in a 3-year rotation sequence. The experimental set-up was a randomized 
block design consisting of $9.1 \times 27.4 \mathrm{~m}$ plots with each crop rotation replicated across four blocks. The plots received no external chemical amendments (i.e. fertilizer or pesticides) and the same annual chisel plow tillage to a depth of $15 \mathrm{~cm}$. For further details on the experimental design and agronomic management practices see Smith et al. (2008).

Soils were collected on November 15, 2011 after corn harvest from the following rotations: monoculture corn (mC), corn-soy (CS), corn-soy-wheat (CSW), corn-soy-wheat with red clover cover crop (CSW1), and corn-soy-wheat with red clover and cereal rye (Secale cereale) cover crops (CSW2). All soils were collected from plots coming out of the corn phase in order to avoid confounding effects of current crop differences. Three soil cores were collected within each plot $(0-10 \mathrm{~cm})$, homogenized in the field, and stored on ice in a cooler until arrival at the laboratory. Fresh soils were sieved to $2 \mathrm{~mm}$, brought to 50\% water holding capacity (WHC), then pre-incubated at $25^{\circ} \mathrm{C}$ for 5 days to decompose labile substrates released during soil processing.

\subsection{Crop Residues and Laboratory Soil Incubation}

We collected wheat crop residues during spring 2011 and corn, soy, and red clover residues in fall 2011 (Table 1). Residues were dried at $60{ }^{\circ} \mathrm{C}$ for 3 days, ground to fragments of $\sim 2 \mathrm{~mm}$, and stored until mixed with the soils. To obtain the relative chemical composition of the crop residues we used pyrolosis gas chromatography/mass spectrometry (py-GC/MS; Grandy et al., 2007). After residue addition (at $1.2 \mathrm{~g}$ of residue per $100 \mathrm{~g}$ of dry soil) and thorough mixing, each soil-residue mixture was divided evenly into three analytical replicates for destructive sampling over the course of the incubation. Each replicate soil sample was placed in a $50 \mathrm{ml}$ test tube, and all three replicate test tubes were placed into a 1 quart canning jar. Jars were placed in 
a dark environmental chamber set at $25^{\circ} \mathrm{C}$ and were capped to prevent moisture loss, but caps were frequently removed to prevent $\mathrm{CO}_{2}$ build-up. Soil moisture was monitored and maintained at $50 \%$ WHC by adding deionized water.

\section{$2.3 \mathrm{CO}_{2}$ Measurements}

To measure soil respiration rates we began by un-capping and aerating the jars. Jars were then re-capped using lids fitted with rubber septa. After capping a gas sample was immediately removed via syringe and injected into an infrared gas analyzer (LI-820, LI-COR, Lincoln, NE). Soils were subsequently incubated for 3-24 h before a second gas sample was removed and $\mathrm{CO}_{2}$ measured as above. During the first few days after the residue was added, the soils were capped for $3 \mathrm{~h}$ in order to avoid excess $\mathrm{CO}_{2}$ and provide sufficient $\mathrm{O}_{2}$. As respiration rates decreased, the time jars were capped increased to 6 and then eventually $24 \mathrm{~h}$ when respiration rates were low (about 3 months after residue addition). Soil respiration rate was calculated as the difference in $\mathrm{CO}_{2}$ concentration between the two sampling time points. We measured respiration rates more frequently at the beginning of the experiment (daily) and less frequently toward the end of the incubation (approximately every other month) for a total of 30 measurements during the study.

\subsection{Extracellular Enzyme Activity, Inorganic N, and Microbial Biomass}

Soil extracellular enzyme activity (EEA) and inorganic $\mathrm{N}$ were measured at four time points: before $\left(\mathrm{T}_{0}\right)$, one $\left(\mathrm{T}_{30}\right)$, three $\left(\mathrm{T}_{90}\right)$, and twelve $\left(\mathrm{T}_{360}\right)$ months after residue addition, which was the end of the incubation. From each jar, we randomly chose an analytical replicate to destructively harvest at each time point during the incubation. We analyzed seven EEAs 
including: $\beta-1,4$,-glucosidase (BG; cleaves glucose from cellobiose, a cellulose dimer); $\beta$-D-1,4cellobiohydrolase ( $\mathrm{CBH}$; cleaves cellobiose from cellulose); $\beta-1,4,-\mathrm{N}$-acetyl glucosaminidase (NAG; cleaves $\mathrm{N}$-acetyl glucosamine from chitin and peptidoglycan oligomers); acid phosphatase (PHOS; cleaves phosphate groups from organic phosphorus), Tyrosine aminopeptidase (TAP; cleaves tyrosine from peptides); phenol oxidase (PO; a lignin oxidizing enzyme); and peroxidase (PER; a lignin oxidizing enzyme that uses peroxide); see Weintraub et al. (2007) for more details on EEAs. Extracellular enzyme activity assays were carried out using soils that were frozen at $-20^{\circ} \mathrm{C}$ following Saiya-Cork et al. (2002) with minor modifications. Running EEA on fresh samples is preferred as freezing can decrease absolute activity (German et al., 2011; Peoples and Koide, 2012), but other studies found no effect of freezing on EEAs (Lee et al., 2007) or inconsistent effects among enzymes (DeForest, 2009). We froze soils due to the large number of soil samples at each destructive harvest and our understanding that relative changes in EEA among treatments are less affected by freezing (Lee et al., 2007; Peoples and Koide, 2012). Briefly, using a blender we homogenized $1 \mathrm{~g}$ of soil in $80 \mathrm{ml}$ of sodium acetate buffer at $\mathrm{pH} 5.6$ (the average soil $\mathrm{pH}$ at the site). After pipetting soil slurries, enzyme substrates and appropriate standards (L-DOPA for oxidase and MUF for hydrolase enzymes) into 96-well plates, soils were incubated at $20^{\circ} \mathrm{C}$ for $6 \mathrm{~h}$ (BG, CBH, NAG, and PHOS) or $18 \mathrm{~h}$ (TAP, PO, and PER). At the end of the enzyme incubation, a Synergy 2 plate reader (BioTek Instruments, Inc., Winooski, VT USA) was used to determine fluorescence at $365 \mathrm{~nm}$ excitation and $460 \mathrm{~nm}$ emission or absorbance at $460 \mathrm{~nm}$ in the case of PO and PER.

We extracted soil inorganic $\mathrm{N}$ from soils at all time points ( $\mathrm{T}_{0}$ to $\mathrm{T}_{360}$ ) by combining $5 \mathrm{~g}$ soil samples with $40 \mathrm{ml} 0.5 \mathrm{M} \mathrm{K}_{2} \mathrm{SO}_{4}$, shaking overnight, and then filtering the resulting soil slurries through Whatman GF/C (5) filters. Filtrates were frozen and stored at $-20^{\circ} \mathrm{C}$ until 
analysis. Concentrations of nitrate $\left(\mathrm{NO}_{3}^{-}\right)$and ammonium $\left(\mathrm{NH}_{4}{ }^{+}\right)$in soil extracts were determined colorimetrically according to the "packet" (Hach; Loveland, CO 80539, USA) methods outlined in Doane \& Horwath (2003) and Sinsabaugh et al. (2000), respectively.

Microbial biomass $\mathrm{C}$ and $\mathrm{N}$ were measured on initial soil samples $\left(\mathrm{T}_{0}\right)$ and at $30 \mathrm{~d}\left(\mathrm{~T}_{30}\right)$ because of large declines in microbial biomass and activity that typically occur after $30 \mathrm{~d}$ in these types of incubations (Rinkes et al., 2011). Microbial biomass was determined using a modification of the chloroform-fumigation extraction method (Scott-Denton et al., 2006; Vance et al., 1987). Briefly, for each soil, two $5 \mathrm{~g}$ soil samples were placed into duplicate $50 \mathrm{ml}$ centrifuge tubes. We added $1 \mathrm{ml}$ of ethanol-free chloroform to one set of the duplicates and immediately capped them. The capped chloroform and non-chloroform soils were placed in a fume hood for $24 \mathrm{~h}$ before caps were removed and soils aerated for $1 \mathrm{~h}$. Finally, all soil samples were extracted with $40 \mathrm{ml} 0.5 \mathrm{M} \mathrm{K}_{2} \mathrm{SO}_{4}$ for $1 \mathrm{~h}$ on an orbital shaker and resulting soil slurries filtered through Whatman \#1 filters. We determined total organic C (TOC) and total N (TN) in the extracts on a TOC-TN analyzer (TOC-V-CPN, Shimadzu Scientific Instruments Inc., Columbia, MD, USA). Microbial biomass $\mathrm{C}$ or $\mathrm{N}$ was calculated as the difference between TOC or $\mathrm{TN}$ in the chloroformed versus non-chloroformed, and corrected for microbial biomass $\mathrm{C}$ (0.45; Joergensen, 1996) and N (0.54; Brookes et al., 1985) extraction efficiencies.

\subsection{Statistical Analyses}

All data were checked for normality and heterogeneity of variances before statistical analyses. Any variables that were non-normal or showed low heterogeneity were appropriately transformed in order to meet variance analyses assumptions (Zuur et al., 2010). Response variables were analyzed using a 2-way analysis of variance (ANOVA), with Residue and 
Rotation as main effects. Variables measured at more than one time point during the incubation were analyzed with repeated measures ANOVA. The ANOVAs were conducted in SAS 9.3 (SAS Institute, Cary, NC) using the proc mixed function and within main effects we used posthoc $F$ tests to determine significant differences between means. Block was assigned as a random effect variable within the model. Correlations between variables were analyzed using proc corr, and Pearson's correlation coefficients are reported. Model effects were deemed significant at $\alpha \leq$ 0.05, but Type I error associated with multiple ANOVAs was accounted for using the Sidak correction (Šidák, 1967).

A 3-pool, 6-parameter exponential decay equation was used to model $\mathrm{C}$ mineralization in the soil-residue combinations because it had previously been found to best fit residue decomposition data (Adair et al., 2008) and has also been used to calculate three pools in soilonly incubations (Paul et al., 1999). The $\mathrm{CO}_{2}$ data were modeled in SigmaPlot v12.5 (Systat Software, San Jose, CA) using a 6-parameter exponential decay macro. The equation for the model is:

$$
\mathrm{F}=M_{1} e^{-k_{1} t}+M_{2} e^{-k_{2} t}+M_{3} e^{-k_{3} t}
$$

Where $\mathrm{F}$ is the $\mathrm{CO}_{2}$ production rate and $\mathrm{M}_{1-3}$ are the three respiration rates and $k_{1-3}$ are the decay constants associated with 'Active', 'Slow', and more 'Resistant' portions of the respiration curve. Active $\mathrm{C}$ pool was calculated by $\mathrm{M}_{1} / k_{1}$, Slow $\mathrm{C}$ pool by $\mathrm{M}_{2} / k_{2}$, and Resistant $\mathrm{C}$ pool by $\mathrm{M}_{3} / k_{3}$. The Active $\mathrm{C}$ pool represents the portion of the respiration curve dominated by the respiration of easily accessible $\mathrm{C}$ and is considered to be composed of soluble, low-molecular weight compounds (e.g. carbohydrates and amino acids) that are most easily accessible by the soil microbial community. The Slow $\mathrm{C}$ pool represents the portion of the respiration curve 
dominated by intermediately available compounds (e.g. hemi-cellulose and cellulose) that are less accessible than the Active $\mathrm{C}$ pool. The Resistant $\mathrm{C}$ pool is the most recalcitrant fraction of the soil-residue respiration curve, where respiration rates often slow to an asymptote. This pool is thought to consist of compounds not easily accessible to the soil microbial community due to their chemical recalcitrance, shielding by lignin, or association with mineral surfaces. When the soil-residue curves were modeled the $\mathrm{R}^{2}$ values were all $>0.90$.

We used a multivariate approach to test for significant effects of residue, rotation and the interaction between residue and rotation across all EEA via MANOVA and used principal components analysis (PCA) to visualize relationships among treatments. The multivariate analyses were done in R (The R Foundation for Statistical Computing, Vienna, Austria). Environmental, or predictor, variables were analyzed for correlation with the PCA using the envirfit function, and variables were deemed significant at $\alpha \leq 0.05$.

\section{Results}

The initial ( $\mathrm{T}_{0}$; soil without residue addition) soil $\mathrm{C}, \mathrm{N}, \mathrm{NO}_{3}{ }^{-}$, and $\mathrm{NH}_{4}{ }^{+}$were not significantly different among cropping treatments. However, we found initial treatment effects on soil C:N ratio $(P<0.001)$, with CS and CSW1 soils significantly greater than CSW soils (Table 2). Further, $\mathrm{T}_{0}$ soils showed treatment differences in basal respiration $(P<0.001)$, with basal respiration generally increasing with crop biodiversity. $\mathrm{T}_{0}$ microbial biomass $\mathrm{C}(\mathrm{MBC})$ and $\mathrm{N}(\mathrm{MBN})$ also both increased with crop biodiversity, but only MBN showed significant differences among treatments (Table 2). Initial enzyme activities from the crop rotations also showed significant differences (Fig. 1); we observed increases in hydrolase (BG, CBH, NAG, 
and TAP) enzyme activities by as much as $46 \%$ and decreases in oxidoreductase (PO and PER) activities by as much as $20 \%$ with increased crop biodiversity.

\section{1 $\mathrm{CO}_{2}$ Dynamics}

The soils with no residue amendments showed strong differences in potential respiration rates and final potentially mineralizable C (Fig. 2), with higher rates and greater cumulative $\mathrm{C}$ respired in more diverse crop rotations. Compared to monoculture $(\mathrm{mC})$, rotations of 2 to 5 crops increased potentially mineralizable C by $28,36,125$, and $86 \%$ for the CS, CSW, CSW1, and CSW2 rotations respectively. This trend also extended to the potentially mineralizable C when expressed as a percent of total C $(32,36,83$, and $66 \%)$. When the residues were added, soils respired an average of $11.8 \mathrm{mg} \mathrm{CO}_{2}-\mathrm{C} \mathrm{g}$ soil $^{-1}$ across all litter types over the $360 \mathrm{~d}$ incubation. Cumulative $\mathrm{CO}_{2}$ production showed both a significant Residue $(P<0.001)$ and Rotation $(P<0.001)$ effect, but no significant interaction (Fig. 3 and Table 3 ). More diverse rotations, especially the rotations with cover crops (CSW1 and CSW2), cumulatively respired more $\mathrm{CO}_{2}-\mathrm{C}$ (Fig. 3 and Table 3). Averaged across all residue types, crop rotational history increased cumulative $\mathrm{CO}_{2}$ production by $0.2,5.3,8.3$, and $6.6 \%$ in CS, CSW, CSW1, and CSW2 respectively, compared to $\mathrm{mC}$.

The 3-pool, 6-parameter exponential decay equation effectively modeled residue decomposition with an average $\mathrm{R}^{2}$ value of 0.96 . Decomposition kinetics varied by residue and the rotation history from which the soil came from (Fig. 3, Table 3, and Table S1). Rotational diversity had the greatest effect on respiration and kinetics early in the incubation and thus on decomposition of more labile pools. For instance, there was a significant Residue*Rotation 
effect on the 3-pool model $k_{1}$ and $\mathrm{M}_{1}$ parameters (Table S1). This was also reflected in the Residue* Rotation effect on the Active $\mathrm{C}$ pool $(P<0.001$, Fig. 1$)$ and Slow $\mathrm{C}$ pools $(P=0.028$, Fig. 2) of potentially mineralizable $\mathrm{C}$ calculated from these parameters. There were very small Active $\mathrm{C}$ pools in the poorest quality residue (Corn and Wheat) and soil combinations, especially for the lower diversity rotations compared to higher diversity rotations (Fig. 3). The CSW2 rotation soils plus corn and wheat residues had $\sim 10$ to 50 times greater Active $\mathrm{C}$ pools compared to $\mathrm{mC}$ soil combinations with those residues.

Residue quality was strongly correlated with overall cumulative $\mathrm{CO}_{2}$ (Table 4), with residue $\mathrm{C}: \mathrm{N}$ correlating most strongly with cumulative respiration $(\mathrm{r}=-0.77)$. The Active $\mathrm{C}$ pool also correlated positively with residue $\mathrm{C}, \mathrm{N}$, and residue protein abundance $(\mathrm{r}=0.57,0.69,0.58)$, but negatively with $\mathrm{C}: \mathrm{N}$ and relative lignin abundance $(\mathrm{r}=-0.68$ and -0.51$)$. The Resistant $\mathrm{C}$ pool showed the opposite relationship with lignin $(r=0.47)$ and protein $(r=-0.52)$.

\subsection{Soil Inorganic $N$}

Soil $\mathrm{NH}_{4}{ }^{+}$and $\mathrm{NO}_{3}{ }^{-}$generally increased over time during the $360 \mathrm{~d}$ incubation (Fig. 4). Concentrations of $\mathrm{NH}_{4}{ }^{+}$were very low and inconsistent within residue and soil treatments. Therefore, we combined $\mathrm{NH}_{4}{ }^{+}$and $\mathrm{NO}_{3}{ }^{-}$into dissolved inorganic $\mathrm{N}$ (DIN). Patterns in DIN concentrations reflected residue C:N (Fig. 4); the residues with high C:N (Corn and Wheat) had lower overall DIN concentrations throughout the incubation. Both Corn and Wheat residues had the greatest increase in DIN between Days 90 and 360 in DIN. Similar to C mineralization, the lower-quality residues showed the most prominent treatment effects and had lower variation. This is in contrast to the higher-quality residues (Soy and Red Clover) that exhibited increases in 
DIN from Day 0 and 30 and large variation. Both Residue and Rotation $(P<0.001$ and $P=$ 0.004, respectively; repeated measures ANOVA) had significant effects on soil DIN (Table 3). Averaged across all residue types, crop rotational history changed cumulative DIN by $-16,-54$, +7 , and $+36 \%$ in CS, CSW, CSW1, and CSW2 respectively, compared to mC.

\subsection{Microbial Biomass and Extracellular Enzyme Activities}

Microbial biomass (MB) at $30 \mathrm{~d}$ was increased, compared to $\mathrm{T}_{0}$, in all residue and crop rotation combinations. For instance, the mean $\mathrm{T}_{0} \mathrm{MBC}$ for all crop rotations was $294 \pm 122 \mathrm{mg}$ $\mathrm{kg} \mathrm{soil}^{-1}$. Thirty days after residue additions the average MBC increased to $638 \pm 154,738 \pm$ 106, $537 \pm 156$, and $543 \pm 202 \mathrm{mg} \mathrm{kg} \mathrm{soil}^{-1}$ for Red Clover, Soy, Corn and Wheat residues. Microbial biomass showed significant Residue*Rotation interactions (Table 3). Microbial biomass $\mathrm{C}$ generally was lower in the residue with greater $\mathrm{C}: \mathrm{N}$ ratio (Fig. 5). Within the corn residue, crop rotations generally increased $\mathrm{MBC}$ at $30 \mathrm{~d}$ after residue addition compared to $\mathrm{mC}$. However, within the wheat residue both CS and CSW had greater MBC than soils from the most diverse crop rotation (CSW2). Microbial biomass $\mathrm{N}$ increased with crop rotations in the two high-quality residues (Red Clover and Soy), except for the Red Clover added to the CSW soil. Conversely, MBN did not differ as much among crop rotation histories when lower quality residues were added, except for the CSW2 rotation having lower MBN than all other rotations within Wheat residue (Fig. 5). Crop diversity decreased the MBC:MBN, relative to mC with higher quality residues (Red Clover and Soy), but had little effect on MBC:MBN when lowerquality residues were added.

Extracellular enzyme activities (EEA), like inorganic $\mathrm{N}$ concentrations, generally increased during the initial stage of decomposition, but then some residue and soil combinations 
declined in later stages (Fig. S1). The MANOVA results showed significant main effects (Table 3), but no interactions. Corn and Wheat, low-quality residues, were associated with lower hydrolase activities, but greater oxidoreductase activities, compared to the high-quality residues (Fig. 6). Multivariate principal components analysis (PCA) allowed us to determine shifts in cumulative EEAs, which reflect total microbial investment in enzyme production during the incubation, due to crop rotation and residue. Similar to other studies that have used PCA for EEAs (Saiya-Cork et al., 2002; Sinsabaugh, 2010; Zeglin et al., 2007), we found that the hydrolase and oxidoreductase enzymes separated out onto different axes (Fig. 6). The overall effect of crop rotation on EEA is also clearly seen along PC1, with the two cover crop rotations (CSW1 and CSW2) having greater hydrolase activity compared to that of the other rotations and $\mathrm{mC}$, during the entire incubation.

The temporal dynamics of EEA showed that microbial investment in $\mathrm{C}$ vs $\mathrm{N}$ acquisition, expressed as the ratio of $\mathrm{C}$ to $\mathrm{N}$ acquiring enzymes, $\mathrm{BG}+\mathrm{CBH} / \mathrm{NAG}+\mathrm{TAP}$, declined drastically after litter addition at $30 \mathrm{~d}$ (Fig. 7). This indicates that after residue addition the microbial community shifted resources toward $\mathrm{N}$ acquisition in response to the addition of $\mathrm{C}$ rich crop residue. Also, the poorer quality residues showed greater dips in this ratio reflecting these residues' high C:N. After $30 \mathrm{~d}$ the $\mathrm{C}$ to $\mathrm{N}$ acquiring enzyme ratio increased as microbes became progressively more $\mathrm{C}$, and less $\mathrm{N}$, limited over the incubation. The $\mathrm{BG}: \mathrm{PO}$ ratio, reflecting cellulose (BG) to lignin (PO) breakdown and the degree to which microbes have to degrade lignin to access cellulose $\mathrm{C}$, decreased over the $365 \mathrm{~d}$ incubation. There was no significant residue effect on the BG:PO (Table 3, Fig. 7), only a significant crop rotation effect. Increasing diversity of the crop rotation increased the BG:PO across all litters (Fig. 6), and the monoculture corn treatment had markedly lower BG:PO values across all litters and through time. 
Enzyme efficiencies, defined as the cumulative amount of $\mathrm{CO}_{2}$ emitted (or mass lost for residue) per unit cumulative enzyme activity, are commonly used as indicators of the return on microbes' investment in enzyme production (Amin et al., 2013; Rinkes et al., 2013; Wickings et al., 2012). Soil enzyme efficiencies also showed significant main effects of Residue $(P<0.001)$ and Rotation $(P<0.001)$, but no interaction (Table 3, Fig. S2). Red clover, although considered a high-quality residue, required relatively more EEA (hydrolase) for the same amount of $\mathrm{CO}_{2}$ produced. Generally, across all residues, greater crop rotational diversity increased oxidoreductase efficiencies, while decreasing hydrolase efficiencies.

Extracellular enzyme activities correlated well with residue chemistry, initial soil parameters, and $\mathrm{NO}_{3}{ }^{-}$and $\mathrm{CO}_{2}$ dynamics over the incubation $(P$ values $<0.04$, Fig. S3). In the initial stages of decomposition $\left(\mathrm{T}_{0}-\mathrm{T}_{30}\right)$, phosphatase showed a strong positive correlation with respiration rates, and a strong negative correlation with PO. During the intermediate stage of decomposition ( $\left.\mathrm{T}_{30}-\mathrm{T}_{90}\right)$ both PO and PER exhibited strong correlations with respiration rates. In the later stages of decomposition $\left(\mathrm{T}_{90}-\mathrm{T}_{360}\right)$, all the hydrolases were negatively correlated with respiration rates, but PO and PER were positively correlated with these rates. These data suggest that as the incubation progressed all soil microbes became increasingly reliant on more recalcitrant substrates.

\section{Discussion}

Although crop rotations are widely used in the U.S. for their agronomic benefits, rotations are typically short (e.g. two crops, corn-soy) and their long-term use is threatened by intensifying demand for a small number of food and fuel crops. Using a unique, long-term 
agricultural crop diversity experiment, we show that crop rotations induced changes in the microbe-SOM interactions that regulate soil $\mathrm{C}$ and $\mathrm{N}$ availability, and that such changes shape the processing of new residue inputs varying in chemistry. More specifically, our results point to monocultures bringing about suppressed microbial activity, which is likely due to substrate limitation, a phenomenon observed in reductions in absolute respiration rates and changes in microbial resource acquisition via extracellular enzymes and biomass C-to-N. At the field-scale, the enhanced microbial activity and increase of microbe-available SOM found in more diverse cropping systems are likely promoting improved crop yields (Smith et al., 2008) as well as influencing positive changes in long-term soil $\mathrm{C}$ dynamics, compared to their monoculture counterparts.

\subsection{The Crop Rotation Effect on $C$ and N Dynamics}

Laboratory incubations allowed for the direct analysis of crop rotation history on decomposition of high and low quality residues without environmental variability. With controlled environmental conditions and the homogenization of soil and crop residues, we could isolate soil microbiological and chemical responses to over a decade of crop diversification and also to contemporary residue inputs. Eleven years of crop rotations influenced initial $\left(\mathrm{T}_{0}\right)$ soil biological characteristics, (basal respiration, microbial biomass $\mathrm{N}$, and extracellular enzyme activities; Table 2), but had little effect on total $\mathrm{C}$ and $\mathrm{N}$ or inorganic $\mathrm{N}$. High measurement variability appears to be limiting our ability to detect changes in total soil C and $\mathrm{N}$ (Kravchenko

et al. 2006), but in a related study sand-corrected C concentrations (which eliminate the mass of $\mathrm{C}$ and $\mathrm{N}$ free sand particles) are different among treatments (e.g. CSW1, $22.6 \mathrm{~g} \mathrm{C} \mathrm{kg}^{-1} \mathrm{sand}_{\text {free }}$ soil vs mC, $17.0 \mathrm{~g} \mathrm{C} \mathrm{kg}^{-1}$ sand free soil; Tiemann et al., in review). Furthermore, Tiemann et al. 
(in review) showed that increases in crop diversity through rotation increased aggregate stability and altered microbial community composition, which we expect are related to the changes in microbial-SOM dynamics we measured here. Total respired C (without residues, Fig. 2) exhibited the strongest responses to rotational diversity, with $125 \%$ greater $\mathrm{C}$ respired in the four crop rotation (85\% when corrected for total soil C concentrations) and $83 \%$ greater in the five crop rotation (66\% when corrected for total soil C concentrations) compared to $\mathrm{mC}$. Although differences in initial soil characteristics were strongest in the most diverse 4-5 crop rotations that included cover crops, we also observed higher respiration rates in CS $(28 \% ; 36 \%$ when corrected for total soil C) and CSW (32\%; 36\% when corrected for total soil C), as well as greater microbial biomass and higher extracellular enzyme activities in these two treatments, compared to $\mathrm{mC}$ (Fig. 1, Table 2).

Potential C mineralization rates provide insights into microbial-available carbon, which encompasses a soil's potential biological activity, nutrient provisioning, and capacity for structure formation, as well as serving as an early indicator of longer-term changes in soil C and $\mathrm{N}$ availability and $\mathrm{C}$ storage. Several studies have shown that agriculture intensification can lead to lowered potential respiration rates and pools of mineralizable $\mathrm{C}$ in laboratory incubations. More specifically, inorganic N fertilizer (Al-Kaisi et al., 2008; Grandy et al., 2013), soil tillage (Doyle et al., 2004; Grandy and Robertson, 2007), and even lack of crop diversity (Doyle et al., 2004; Franzluebbers et al., 1995, 1994) have been shown to decrease this pool of microbialavailable $\mathrm{C}$. Although other studies have found crop rotations to have nil or a negative effect on potentially mineralizable C (Meriles et al., 2009; Sainju et al., 2007), we found crop rotation strongly increased potential respiration rates. The variations in the effect of crop rotations on 
this labile $\mathrm{C}$ pool appears to be linked to the crop species studied, and are likely due to the differences in plant contributions to this microbial-available pool of SOM.

Substrate limitation is likely underlying the low potential respiration rates and microbial biomass in the simple compared to more complex rotations. The two lines of evidence supporting this argument are the significantly lower cumulative $\mathrm{CO}_{2}$ respired per unit soil $\mathrm{C}$ in $\mathrm{mC}$ compared to the more complex rotations and also the lower ratio of $\beta$-glucosidase-to-phenol oxidase (BG:PO). $\beta$-glucosidase is an extracellular enzyme involved in degrading cellulose, a relatively labile substrate; whereas phenol oxidase breaks down lignin, and has been attributed to microbial C and N mining from soil and plant cell walls (Sinsabaugh et al., 2005; Talbot et al., 2008; Waldrop et al., 2004). In our incubation the BG:PO ratio remained lower in the monoculture corn treatment over the entire incubation, regardless of the residue added to the soils (Fig. 6), indicating that rotation history has selected for a microbial community adapted to degradation of poorer quality or more recalcitrant $\mathrm{SOM}$ in order to acquire $\mathrm{C}$ in the $\mathrm{mC}$ soil. The BG:PO ratio is correlated with SOM quality (Sinsabaugh and Follstad Shah, 2011) and is also considered an indicator of soil disturbance from land use change or management (Sinsabaugh, 2010). Land management practices that decrease SOM quantity and/or quality are found to increase PO, thereby decreasing the BG:PO ratio (Sinsabaugh and Follstad Shah, 2011; Sinsabaugh, 2010). Thus, the depletion of labile substrates in the monoculture corn is clearly indicated by the declines in potential respiration rates as well as the changes in microbial activity and substrate acquisition strategies.

\subsection{Residue Characteristics Regulating C and N Dynamics}


Because of the wide range in chemical composition between high- and low-quality litters (Table 1), residue quality strongly regulated microbial biomass, extracellular enzyme activities, and the byproducts of decomposition $\left(\mathrm{CO}_{2}\right.$ and dissolved inorganic N) (Fig. S4). The strong residue effect is apparent in the consistent differences between the Red Clover and Soy versus the Corn and Wheat residues (Table 3), especially for soil enzyme activities. We measured soil extracellular enzymes in this study to represent microbial investment in $\mathrm{C}$ and nutrient acquisition, which reflects the supply and demand of substrate C and N. Although recent studies suggest that enzyme activities can be decoupled from substrate availability (Hernández and Hobbie, 2010; McDaniel et al., 2013), others find the two are tightly linked (Grandy et al., 2009; Wickings et al., 2012) with the strength of the relationship likely dependent upon the type of enzyme (i.e. constitutive vs. inductive) and the relative influence of abiotic controls (e.g. texture and soil moisture). In this study, we showed that the extracellular enzyme dynamics were strongly related to substrate supply (residue chemistry and initial soil C and $\mathrm{N}$ pools) as well as measures of demand $\left(\mathrm{CO}_{2}\right.$ and microbial biomass $\left.\mathrm{C}: \mathrm{N}\right)$. For instance, the $\mathrm{CO}_{2}$ produced in the initial 0-30 days of incubation was inversely related to polyphenol oxidase and peroxidase enzymes used in recalcitrant SOM decomposition. This is likely due to the soil microbial communities' reliance on mostly labile forms of $\mathrm{C}$ and $\mathrm{N}$ during this stage. In contrast, during the later stages of decay (90-360 d) these same enzymes were positively related to $\mathrm{CO}_{2}$ indicating their role in accessing more recalcitrant forms of $\mathrm{C}$ and $\mathrm{N}$ later in the incubation. There were few interactive effects of residues and crop rotation history on extracellular enzyme activity, although many enzyme responses showed significant main effects (Table 3). When data were corrected for soil C, there were still no significant interactions between residue type and 
crop rotation, suggesting that the large amount of residue we added was likely an overriding factor.

After residue addition, the chemistry of added litter inputs was a stronger control on respiration rates than crop rotation history (Table 3), although crop rotation did have direct effects on decomposition dynamics. For instance, averaged across all residue types we found that the soils from more complex rotations had more rapid respiration rates and greater cumulative respiration potential (Fig. 3). The four and five crop rotations increased cumulative respiration 8.3 and $6.6 \%$, respectively, compared to the monoculture corn soil across all residue types. Soil inorganic $\mathrm{N}$ accumulation during the incubation was more varied than respiration. Across all residue types, final cumulative soil inorganic $\mathrm{N}$ was $54 \%$ less in the CSW rotation, but $35 \%$ more in the CSW2 rotation, compared to that of monoculture corn (Fig. 4). Enhanced inorganic $\mathrm{N}$ concentrations suggest more rapid $\mathrm{N}$ mineralization in highly diverse rotations, which was also suggested by Sanchez et al. (2001), who found that a C-C-S-W rotation with three cover crops mineralized $40 \%$ more $\mathrm{N}$ from added substrates than a monoculture corn soil. In our study, the marked accumulation of inorganic $\mathrm{N}$ may be linked to cover crop interactions. For instance, the CSW1 rotation had only a 7\% increase in inorganic N (and non-significant, Fig 4.) relative to the monoculture soil. Soil from this rotation included both $\mathrm{N}$-fixing crops (soy and red clover), but did not include the rye cover crop mixed with the red clover, indicating that the addition of a non- $\mathrm{N}$-fixing cover crop greatly enhanced $\mathrm{N}$ mineralization rates. Overall, diversifying rotations appears to increase $\mathrm{C}$ availability more or less linearly, but $\mathrm{N}$ mineralized from newly added residues is more varied and is related to cover crop dynamics.

Crop rotation and residue interactions influenced only the Active $\mathrm{C}$ pool and microbial biomass. For example, the five-crop rotation soils with corn or wheat residues had Active $\mathrm{C}$ 
pools ten to fifty times that of monoculture corn, but there was no effect on Active $\mathrm{C}$ in soils with more labile and $\mathrm{N}$-rich clover or soy residues (Fig. 3). Furthermore, microbial biomass $\mathrm{N}$ was increased, and microbial C:N ratios decreased, by combining increased rotation complexity with the addition of high-quality residues (Red Clover and Soy). This indicates that microbial N status is improved in soils under more diverse rotations with high quality residues. Our results combined with those from field studies showing large increases in microbial biomass, particularly MBN (Ekenler and Tabatabai, 2002; McDaniel et al., 2014), with increased rotation complexity point to a microbial-driven mechanism where soils in more diverse crop rotations accrue $\mathrm{N}$.

Microbial biomass and nutrient cycling are influenced by both the historical effects of rotation and their interaction with contemporary residue inputs. The mechanisms driving these rotation and residue dynamics remains uncertain, but likely involve changes to the structure or function of the microbial community and substrates available to that community. In our study, the enhanced Active $\mathrm{C}$ pool in soils with corn and wheat residues combined with the most diverse crop rotation may have resulted from cometabolism of pre-existing substrates in the SOM (Kuzyakov, 2010; Paterson et al., 2009), whereby cometabolism refers to the use of native SOM to decompose fresh residue inputs. Indeed, crop rotations can increase the size of mineral soil C pools and alter their biochemical composition (Ding et al., 2011; Ryszkowski et al., 1998; Senwo and Tabatabai, 1998). Therefore, soil microbes in the diverse rotations will have access to greater quantity and quality of substrates for cometabolizing new inputs of recalcitrant residues. Prior to residue additions in our study, the large differences in respiration and soil enzyme ratios indicate that substrate availability likely differed among crop rotation treatments. This is especially true for the cellulose-to-lignin-degrading enzyme ratio (BG:PO), which 
indicates that soils from more diverse rotations have more available substrates and thus rely less on recalcitrant sources to obtain $\mathrm{C}$ or $\mathrm{N}$.

In addition to available $\mathrm{C}$ and nutrient resources, rotations may have altered the function and structure of belowground communities; both the shifts in enzyme activities (Fig. 6) and the changes in microbial $\mathrm{C}$ and $\mathrm{N}$ after residue addition (Fig. 5) point to changes in the general microbial community with increased crop diversity. Similarly, Eisenhauer et al. (2010) found in grasslands that microbial biomass and function increased with increasing plant species richness. In agroecosystems, both soil microbial communities (Lupwayi et al., 1998; Wu et al., 2008; Xuan et al., 2012) and measures of their functional capacity like extracellular-enzymes (AcostaMartínez et al., 2010; Dodor and Ali Tabatabai, 2005) are also enhanced by rotations. Thus, changes in microbial community composition could also explain differences in residue decomposition in soils from different rotation histories.

\subsection{Conclusions}

Our research highlights the importance of crop rotations as a viable means to increase aboveground biodiversity while enhancing soil functioning. Although all of the soils used in our experiment were under the same crop (corn) for the year, crop rotation history strongly influenced how contemporary residues were processed. Moreover, these results provide insight into the mechanisms underlying what is colloquially referred to as the 'rotation effect', or the increase in yield often observed in crop rotations. While the rotation effect is typically attributed to declines in weed or insect pest pressure, we show that enhanced retention of $\mathrm{N}$ in microbial biomass decomposing high quality residues, more rapid decomposition of low-quality residues, and overall higher microbial activity point to more tightly coupled crop-soil-microbe 
relationships in biodiverse cropping systems. These soil processes improved by crop rotation then likely feedback to positively influence plant productivity. Given that conversion of natural systems to agriculture can result in soil C and $\mathrm{N}$ losses of 30-50\% (Davidson and Ackerman, 1993; Grandy and Robertson, 2007), soil-atmosphere greenhouse gas increases (Grandy and Robertson, 2006), and losses of soil ecosystem functions such as nutrient and water retention (Guo and Gifford, 2002; Zhang and Schilling, 2006), agricultural plant communities should be strategically diversified using rotations to restore soil biological interactions and ecosystem services.

\section{Acknowledgements}

We are grateful for financial support from the United States Department of Agriculture Soil Processes Program, grant \#2009-65107-05961. Financial support was also provided by the US DOE office of Science (DE-FCO2-07ER64494), the Office of Energy Efficiency and Renewable Energy (DE-ACO5-76RL01830), and the US National Science Foundation LTER Program (DEB 1027253). Support for this research was also provided by the NSF Long-Term Ecological Research Program at the Kellogg Biological Station and by the New Hampshire Agricultural Experiment Station and Michigan State University AgBioResearch. We would like to thank Stacey VanderWulp for logistical help with collecting crop residues and help with field work. Also we would like to extend a special thanks Natasha Lessard for helping with laboratory work, Cynthia Kallenbach, Andrea Jilling, Amanda Daly, and Michael Castellano for feedback on earlier drafts of the manuscript. Finally, we would like to acknowledge Kay Gross and Phil Robertson who originally established these sites and have kindly provided our research team with access to them. 


\section{List of Tables}

Table 1. Initial residue chemical composition.

Table 2. Initial $\left(\mathrm{T}_{0}\right)$ soil biogeochemical parameters for the five crop rotation treatments.

Table 3. ANOVA effects of Residue, Crop Rotation, and the interaction on all measured responses to residue addition.

Table 4. Pearson correlation coefficients (r) between chemical compounds and decomposition parameters $(n=75)$. 


\section{List of Figures}

Figure 1. Extracellular enzyme activities (EEA) of the initial soils collected November 15, 2011. The EEA units were measured in nano moles of enzymatic product produced per hour per gram of soil organic carbon (SOC). Treatment abbreviations are: $\mathrm{mC}=$ monoculture corn, $\mathrm{CS}=$ corn-soy, CSW $=$ corn-soy-wheat, $\mathrm{CSW} 1=$ corn-soy-wheat + red clover cover crop, $\mathrm{CSW} 2=$ corn-soy-wheat + rye and red clover cover crops. EEA abbreviations are: $\mathrm{BG}=\beta$ 1,4,-glucosidase, $\mathrm{CBH}=\beta$-D-1,4-cellobiohydrolase, $\mathrm{NAG}=\beta$-1,4,-N-acetyl glucosaminidase, $\mathrm{PHOS}=$ acid phosphatase, $\mathrm{TAP}=$ Tyrosine aminopeptidase, $\mathrm{PO}=$ phenol oxidase, and PER $=$ peroxidase. Significant differences are shown with letters above the bars $(\alpha=0.05)$.

Figure 2. Cumulative respiration from the soil only (no residue added). Y-axis units are in milligrams of $\mathrm{CO}_{2}$ carbon per gram of dry soil. Inset: Cumulative $\mathrm{CO}_{2}-\mathrm{C}$ expressed as percentage of total soil C. Crop rotation treatment abbreviations are: $\mathrm{mC}=$ monoculture corn, CS = corn-soy, CSW = corn-soy-wheat, CSW1 = corn-soy-wheat + red clover cover crop, CSW2 = corn-soy-wheat + rye and red clover cover crops. Error bars are standard errors $(\mathrm{n}=4)$ for each soil by residue combination.

Figure 3. Cumulative $\mathrm{CO}_{2}$ production curves for all residue and soil combinations over the 360 d incubation (Top Row). Stacked bars of modeled potentially mineralizable C pools (Bottom Row). Pools (Active, Slow, and Resistant C pools) were calculated for individual soil by residue experimental units using a 6-parameter exponential decay equation. Y-axis units for both rows are in milligrams of $\mathrm{CO}_{2}$ carbon per gram of dry soil. Crop rotation treatment abbreviations are: $\mathrm{mC}=$ monoculture corn, $\mathrm{CS}=$ corn-soy, $\mathrm{CSW}=$ corn-soy-wheat, $\mathrm{CSW} 1=$ 
corn-soy-wheat + red clover cover crop, CSW2 $=$ corn-soy-wheat + rye and red clover cover crops. Error bars are standard errors $(n=4)$ for each soil by residue combination.

Figure 4. Soil inorganic $\mathrm{N}\left(\mathrm{NH}_{4}{ }^{+}+\mathrm{NO}_{3}{ }^{-}\right)$pooled by Crop Rotation (Left) and Residue (Right) over the $360 \mathrm{~d}$ incubation. Y-axis units are in milligram of ammonium plus nitrate $\mathrm{N}$ per kilogram of dry soil. Crop rotation treatment abbreviations are: $\mathrm{mC}=$ monoculture corn, $\mathrm{CS}$ = corn-soy, CSW = corn-soy-wheat, CSW1 = corn-soy-wheat + red clover cover crop, CSW2 $=$ corn-soy-wheat + rye and red clover cover crops. Error bars are standard errors $(n=4)$ for each rotation by residue combination.

Figure 5. Soil microbial biomass after 30 days of incubation with crop residues. Y-axes are milligrams of microbial biomass $\mathrm{C}$ (or $\mathrm{N}$ ) per kilogram of dry soil, except for ratios which are unit-less. Crop rotation treatment abbreviations are: $\mathrm{mC}=$ monoculture corn, $\mathrm{CS}=$ cornsoy, CSW = corn-soy-wheat, CSW1 = corn-soy-wheat + red clover cover crop, CSW2 = corn-soy-wheat + rye and red clover cover crops. Error bars are standard errors $(n=4)$ for each rotation by residue combination.

Figure 6. Principal components analysis (PCA) of cumulative enzyme activity pooled by crop rotation and residue (there was no significant interaction). X-axis represents principal component 1 (PC1) which comprises $44.2 \%$ of the PCA variation. Y-axis represents principal component 2 (PC2) which comprises $16.7 \%$ of the PCA variation. Crop rotation treatment abbreviations are: $\mathrm{mC}=$ monoculture corn, $\mathrm{CS}=$ corn-soy, $\mathrm{CSW}=$ corn-soy-wheat, CSW1 = corn-soy-wheat + red clover cover crop, CSW2 $=$ corn-soy-wheat + rye and red clover cover crops. EEA abbreviations are: $\mathrm{BG}=\beta-1,4$,-glucosidase, $\mathrm{CBH}=\beta-\mathrm{D}-1,4-$ cellobiohydrolase, $\mathrm{NAG}=\beta-1,4,-\mathrm{N}$-acetyl glucosaminidase, $\mathrm{TAP}=$ tyrosine aminopeptidase, 
$\mathrm{PO}=$ phenol oxidase. Error bars are standard errors $(\mathrm{n}=4)$ for each rotation or residue mean.

Figure 7. Extracellular enzyme activity (EEA) ratios over the $360 \mathrm{~d}$ incubation. The ratios shown are a C-to-N acquiring enzyme ratio (top row), and a labile-to-recalcitrant enzyme acquisition ratio (bottom row). EEA abbreviations are: $\mathrm{BG}=\beta-1,4$, -glucosidase, $\mathrm{CBH}=\beta$ D-1,4-cellobiohydrolase, $\mathrm{NAG}=\beta-1,4,-\mathrm{N}$-acetyl glucosaminidase, $\mathrm{TAP}=$ tyrosine aminopeptidase, $\mathrm{PO}=$ phenol oxidase. Crop rotation treatment abbreviations are: $\mathrm{mC}=$ monoculture corn, CS $=$ corn-soy, CSW $=$ corn-soy-wheat, CSW1 $=$ corn-soy-wheat + red clover cover crop, CSW2 = corn-soy-wheat + rye and red clover cover crops. Error bars are standard errors $(\mathrm{n}=4)$ for each rotation by residue combination. 


\section{References}

Acosta-Martínez, V., Burow, G., Zobeck, T.M., Allen, V.G., 2010. Soil microbial communities and function in alternative systems to continuous cotton. Soil Science Society of America Journal 74, 1181-1192.

Adair, E.C., Parton, W.J., Del Grosso, S.J., Silver, W.L., Harmon, M.E., Hall, S.A., Burke, I.C., Hart, S.C., 2008. Simple three-pool model accurately describes patterns of long-term litter decomposition in diverse climates. Global Change Biology 14, 2636-2660.

Al-Kaisi, M.M., Kruse, M.L., Sawyer, J.E., 2008. Effect of nitrogen fertilizer application on growing season soil carbon dioxide emission in a corn-soybean rotation. Journal of Environmental Quality 31, 325-332.

Amin, B., Chabbert, B., Moorhead, D., Bertrand, I., 2013. Impact of fine litter chemistry on lignocellulolytic enzyme efficiency during decomposition of maize leaf and root in soil. Biogeochemistry 117, 169-183.

Brookes, P.C., Landman, A., Pruden, G., Jenkinson, D.S., 1985. Chloroform fumigation and the release of soil nitrogen: A rapid direct extraction method to measure microbial biomass nitrogen in soil. Soil Biology and Biochemistry 17, 837-842.

Bullock, D.G., 1992. Crop rotation. Critical Reviews in Plant Science 11, 309-326.

Caporaso, J.G., Lauber, C.L., Walters, W.A., Berg-Lyons, D., Lozupone, C.A., Turnbaugh, P.J., Fierer, N., Knight, R., 2011. Global patterns of 16S rRNA diversity at a depth of millions of sequences per sample. Proceedings of the National Acadamy of Sciences 108, 4516-4522. 
Cardinale, B.J., Duffy, J.E., Gonzalez, A., Hooper, D.U., Perrings, C., Venail, P., Narwani, A., Mace, G.M., Tilman, D., Wardle, D.A., Kinzig, A.P., Daily, G.C., Loreau, M., Grace, J.B., Larigauderie, A., Srivastava, D.S., Naeem, S., 2012. Biodiversity loss and its impact on humanity. Nature 486, 59-67.

Davidson, E., Ackerman, I., 1993. Changes in soil carbon inventories following cultivation of previously untilled soils. Biogeochemistry 20, 161-193.

DeForest, J.L., 2009. The influence of time, storage temperature, and substrate age on potential soil enzyme activity in acidic forest soils using MUB-linked substrates and l-DOPA. Soil Biology and Biochemistry 41, 1180-1186.

Ding, X., Zhang, B., Zhang, X., Yang, X., Zhang, X., 2011. Effects of tillage and crop rotation on soil microbial residues in a rainfed agroecosystem of northeast China. Soil Tillage Research 114, 43-49.

Doane, T.A., Horwáth, W.R., 2003. Spectrophotometric determination of nitrate with a single reagent. Analalytical Letters 36, 2713-2722.

Dodor, D.E., Tabatabai, M.A., 2005. Glycosidases in soils as affected by cropping systems. Journal of Plant Nutrition and Soil Science 168, 749-758.

Doyle, G.L., Rice, C.W., Peterson, D.E., Steichen, J., 2004. Biologically defined soil organic matter pools as affected by rotation and tillage. Environmental Management 33, S528S538. 
Drinkwater, L.E., Wagoner, P., Sarrantonio, M., 1998. Legume-based cropping systems have reduced carbon and nitrogen losses. Nature 396, 262-265.

Eisenhauer, N., Beßler, H., Engels, C., Gleixner, G., Habekost, M., Milcu, A., Partsch, S., Sabais, A.C.W., Scherber, C., Steinbeiss, S., Weigelt, A., Weisser, W.W., Scheu, S., 2010. Plant diversity effects on soil microorganisms support the singular hypothesis. Ecology 91, 485-496.

Ekenler, M., Tabatabai, M.A., 2002. B-Glucosaminidase activity of soils: effect of cropping systems and its relationship to nitrogen mineralization. Biology and Fertility of Soils 36, $367-376$.

Fierer, N., Breitbart, M., Nulton, J., Salamon, P., Lozupone, C., Jones, R., Robeson, M., Edwards, R.A., Felts, B., Rayhawk, S., Knight, R., Rohwer, F., Jackson, R.B., 2007. Metagenomic and small-subunit rRNA analyses reveal the genetic diversity of bacteria, archaea, fungi, and viruses in soil. Applied and Environmental Microbiology 73, 70597066.

Franzluebbers, A.J., Hons, F.M., Zuberer, D.A., 1994. Seasonal changes in soil microbial biomass and mineralizable $\mathrm{C}$ and $\mathrm{N}$ in wheat management systems. Soil Biology and Biochemistry 26, 1469-1475.

Franzluebbers, A.J., Hons, F.M., Zuberer, D.A., 1995. Soil organic carbon, microbial biomass, and mineralizable carbon and nitrogen in sorghum. Soil Science Society America Journal $59,460-466$. 
German, D.P., Weintraub, M.N., Grandy, A.S., Lauber, C.L., Rinkes, Z.L., Allison, S.D., 2011. Optimization of hydrolytic and oxidative enzyme methods for ecosystem studies. Soil Biology and Biochemistry 43, 1387-1397.

Grandy, A.S., Neff, J.C., 2008. Molecular C dynamics downstream: The biochemical decomposition sequence and its impact on soil organic matter structure and function. Science of the Total Environment 404, 297-307.

Grandy, A.S., Neff, J.C., Weintraub, M.N., 2007. Carbon structure and enzyme activities in alpine and forest ecosystems. Soil Biology and Biochemistry 39, 2701-2711.

Grandy, A.S., Robertson, G.P., 2006. Initial cultivation of a temperate-region soil immediately accelerates aggregate turnover and $\mathrm{CO}_{2}$ and $\mathrm{N}_{2} \mathrm{O}$ fluxes. Global Change Biology 12, 15071520.

Grandy, A.S., Robertson, G.P., 2007. Land-use intensity effects on soil organic carbon accumulation rates and mechanisms. Ecosystems 10, 59-74.

Grandy, A.S., Salam, D.S., Wickings, K., McDaniel, M.D., Culman, S.W., Snapp, S.S., 2013. Soil respiration and litter decomposition responses to nitrogen fertilization rate in no-till corn systems. Agriculture, Ecosystems \& Environment 179, 35-40.

Grandy, A.S., Strickland, M.S., Lauber, C.L., Bradford, M.A., Fierer, N., 2009. The influence of microbial communities, management, and soil texture on soil organic matter chemistry. Geoderma 150, 278-286. 
Guo, L.B., Gifford, R.M., 2002. Soil carbon stocks and land use change: a meta analysis. Global Change Biology 8, 345-360.

Hättenschwiler, S., Tiunov, A. V, Scheu, S., 2005. Biodiversity and litter decomposition in terrestrial ecosystems. Annual Review of Ecology, Evolution, and Systematics 36, 191-218.

Heckman, K., Grandy, A.S., Gao, X., Keiluweit, M., Wickings, K., Carpenter, K., Chorover, J., Rasmussen, C., 2013. Sorptive fractionation of organic matter and formation of organohydroxy-aluminum complexes during litter biodegradation in the presence of gibbsite. Geochimica et Cosmochemica Acta 121, 667-683.

Hernández, D., Hobbie, S., 2010. The effects of substrate composition, quantity, and diversity on microbial activity. Plant and Soil 335, 397-411.

Heywood, V.H., 1995. Global biodiversity assessment. Cambridge University Press.

Hooper, D.U., Adair, E.C., Cardinale, B.J., Byrnes, J.E.K., Hungate, B.A., Matulich, K.L., Gonzalez, A., Duffy, J.E., Gamfeldt, L., O’Connor, M.I., 2012. A global synthesis reveals biodiversity loss as a major driver of ecosystem change. Nature 486, 105-108.

Joergensen, R.G., 1996. The fumigation-extraction method to estimate soil microbial biomass: Calibration of the kEC value. Soil Biology and Biochemistry 28, 25-31.

KBS, 2013. W.K. Kellogg Biological Station - LTER Website: www.lter.kbs.msu.edu (Verified November 11, 2013). 
Kou, T.J., Zhu, P., Huang, S., Peng, X.X., Song, Z.W., Deng, A.X., Gao, H.J., Peng, C., Zhang, W.J., 2012. Effects of long-term cropping regimes on soil carbon sequestration and aggregate composition in rainfed farmland of Northeast China. Soil and Tillage Research $118,132-138$.

Kravchenko, A.N., Robertson, G.P., Snap, S.S., \& Smucker, A.J.M. 2006. Using information about spatial variability to improve estimates of total soil carbon. Agronomy Journal 98, 823-829.

Kuzyakov, Y., 2010. Priming effects: Interactions between living and dead organic matter. Soil Biology and Biochemistry 42, 1363-1371.

Lee, Y.B., Lorenz, N., Dick, L.K., Dick, R.P., 2007. Cold storage and pretreatment incubation effects on soil microbial properties. Soil Science Society of America Journal 71,12991305.

Liang, C., Balser, T.C., 2010. Microbial production of recalcitrant organic matter in global soils: implications for productivity and climate policy. Nature Reviews Microbiology 9, 75.

Lupwayi, N.Z., Rice, W.A., Clayton, G.W., 1998. Soil microbial diversity and community structure under wheat as influenced by tillage and crop rotation. Soil Biology and Biochemistry 30, 1733-1741.

McDaniel, M.D., Kaye, J.P., Kaye, M.W., 2013. Increased temperature and precipitation had limited effects on soil extracellular enzyme activities in a post-harvest forest. Soil Biology and Biochemistry 56, 90-98. 
McDaniel, M.D., Tiemann, L.K., Grandy, A.S., 2014. Does agricultural crop diversity enhance soil microbial biomass and organic matter dynamics? a meta-analysis. Ecological Applications 24, 560-570.

Meriles, J.M., Vargas Gil, S., Conforto, C., Figoni, G., Lovera, E., March, G.J., Guzmán, C.A., 2009. Soil microbial communities under different soybean cropping systems:

Characterization of microbial population dynamics, soil microbial activity, microbial biomass, and fatty acid profiles. Soil and Tillage Research 103, 271-281.

Mitchell, C.C., Entry, J.A., 1998. Soil C, N and crop yields in Alabama’s long-term `Old Rotation' cotton experiment. Soil and Tillage Research 47, 331-338.

Mueller, K.E., Hobbie, S.E., Tilman, D., Reich, P.B., 2013. Effects of plant diversity, N fertilization, and elevated carbon dioxide on grassland soil $\mathrm{N}$ cycling in a long-term experiment. Global Change Biology 19, 1249-1261.

Oelmann, Y., Wilcke, W., Temperton, V.M., Buchmann, N., Roscher, C., Schumacher, J., Schulze, E.-D., Weisser, W.W., 2007. Soil and plant nitrogen pools as related to plant diversity in an experimental grassland. Soil Science Society of America Journal 71, 720729.

Padgitt, M., Newton, D., Penn, R., Sandretto, C., 2000. Production Practices for Major Crops in U.S. Agriculture, 1990-97. Statistical Bulletin No. 969. 
Paterson, E., Midwood, A.J., Millard, P., 2009. Through the eye of the needle: a review of isotope approaches to quantify microbial processes mediating soil carbon balance. New Phytolologist 184, 19-33.

Paul, E.A., Harris, D., Collins, H.P., Schulthess, U., Robertson, G.P., 1999. Evolution of $\mathrm{CO}_{2}$ and soil carbon dynamics in biologically managed, row-crop agroecosystems. Applied Soil Ecology 11, 53-65.

Peoples, M.S., Koide, R.T., 2012. Considerations in the storage of soil samples for enzyme activity analysis. Applied Soil Ecology 62, 98-102.

Rinkes, Z.L., Sinsabaugh, R.L., Moorhead, D.L., Grandy, A.S., Weintraub, M.N., 2013. Field and lab conditions alter microbial enzyme and biomass dynamics driving decomposition of the same leaf litter. Frontiers in Microbiology 4, 1-14.

Rinkes, Z.L., Weintraub, M.N., DeForest, J.L., Moorhead, D.L., 2011. Microbial substrate preference and community dynamics during decomposition of Acer saccharum. Fungal Ecology 4, 396-407.

Ryszkowski, L., Szajdak, L., Karg, J., 1998. Effects of continuous cropping of rye on soil biota and biochemistry. Critical Reviews in Plant Sciences 17, 225-244.

Sainju, U.M., Caesar-TonThat, T., Lenssen, A.W., Evans, R.G., Kolberg, R., 2007. Long-term tillage and cropping sequence effects on dryland residue and soil carbon fractions. Soil Science Society of America Journal 71, 1730-1739. 
Saiya-Cork, K.R., Sinsabaugh, R.L., Zak, D.R., 2002. The effects of long term nitrogen deposition on extracellular enzyme activity in an Acer saccharum forest soil. Soil Biology and Biochemistry 34, 1309-1315.

Sala, O.E., Chapin, F.S., III, Armesto, J.J., Berlow, E., Bloomfield, J., Dirzo, R., Huber-Sanwald, E., Huenneke, L.F., Jackson, R.B., Kinzig, A., Leemans, R., Lodge, D.M., Mooney, H.A., Oesterheld, M., Poff, N.L., Sykes, M.T., Walker, B.H., Walker, M., Wall, D.H., 2000. Global biodiversity scenarios for the Year 2100. Science 287, 1770-1774.

Sanchez, J.E., Willson, T.C., Kizilkaya, K., Parker, E., Harwood, R.R., 2001. Enhancing the mineralizable nitrogen pool through substrate diversity in long term cropping systems. Soil Science Society of America Journal 65, 1442-1447.

Scott-Denton, L.E., Rosenstiel, T.N., Monson, R.K., 2006. Differential controls by climate and substrate over the heterotrophic and rhizospheric components of soil respiration. Global Change Biology 12, 205-216.

Senwo, Z.N., Tabatabai, M.A., 1998. Amino acid composition of soil organic matter. Biology and Fertility of Soils 26, 235-242.

Šidák, Z., 1967. Rectangular confidence regions for the means of multivariate normal distributions. Journal of American Statistics Association 62, 626-633.

Simpson, A.J., Simpson, M.J., Smith, E., Kelleher, B.P., 2007. Microbially derived inputs to soil organic matter: Are current estimates too low? Environonmental Science and Technology $41,8070-8076$. 
Sinsabaugh, R., Follstad Shah, J., 2011. Ecoenzymatic stoichiometry of recalcitrant organic matter decomposition: the growth rate hypothesis in reverse. Biogeochemistry 102, 31-43.

Sinsabaugh, R.L., 2010. Phenol oxidase, peroxidase and organic matter dynamics of soil. Soil Biology and Biochemistry 42, 391-404.

Sinsabaugh, R.L., Gallo, M.E., Lauber, C., Waldrop, M.P., Zak, D.R., 2005. Extracellular enzyme activities and soil organic matter dynamics for northern hardwood forests receiving simulated nitrogen deposition. Biogeochemistry 75, 201-215.

Sinsabaugh, R.L., Reynolds, H., Long, T.M., 2000. Rapid assay for amidohydrolase (urease) activity in environmental samples. Soil Biology and Biochemistry 32, 2095-2097.

Smith, R., Gross, K., Robertson, G., 2008. Effects of crop diversity on agroecosystem function: Crop yield response. Ecosystems 11, 355-366.

Suzuki, C., Takenaka, M., Oka, N., Nagaoka, K., Karasawa, T., 2012. A DGGE analysis shows that crop rotation systems influence the bacterial and fungal communities in soils. Soil Science and Plant Nutrition 58, 288-296.

Talbot, J.M., Allison, S.D., Treseder, K.K., 2008. Decomposers in disguise: mycorrhizal fungi as regulators of soil C dynamics in ecosystems under global change. Functional Ecology 22, 955-963.

Tiemann, L.K., Stuart Grandy, A., 2014. Mechanisms of soil carbon accrual and storage in bioenergy cropping systems. Global Change Biology Bioenergy, doi:10.1111/gcbb.12126. 
Tilman, D., Fargione, J., Wolff, B., D’Antonio, C., Dobson, A., Howarth, R., Schindler, D., Schlesinger, W.H., Simberloff, D., Swackhamer, D., 2001. Forecasting agriculturally driven global environmental change. Science 292, 281-284.

Tilman, D., Knops, J., Wedin, D., Reich, P., Ritchie, M., Siemann, E., 1997. The influence of functional diversity and composition on ecosystem processes. Science 277, 1300-1302.

Tonitto, C., David, M.B., Drinkwater, L.E., 2006. Replacing bare fallows with cover crops in fertilizer-intensive cropping systems: A meta-analysis of crop yield and $\mathrm{N}$ dynamics. Agriculture, Ecosystems and Environment 112, 58-72.

Vance, E.D., Brookes, P.C., Jenkinson, D.S., 1987. An extraction method for measuring soil microbial biomass C. Soil Biology and Biochemistry 19, 703-707.

Waldrop, M.P., Zak, D.R., Sinsabaugh, R.L., 2004. Microbial community response to nitrogen deposition in northern forest ecosystems. Soil Biology and Biochemistry 36, 1443-1451.

Weintraub, M., Scott-Denton, L., Schmidt, S., Monson, R., 2007. The effects of tree rhizodeposition on soil exoenzyme activity, dissolved organic carbon, and nutrient availability in a subalpine forest ecosystem. Oecologia 154, 327-338.

Wickings, K., Grandy, A.S., Reed, S.C., Cleveland, C.C., 2012. The origin of litter chemical complexity during decomposition. Ecology Letters 15: 1180-1188.

Wu, T., Chellemi, D., Graham, J., Martin, K., Rosskopf, E., 2008. Comparison of soil bacterial communities under diverse agricultural land management and crop production practices. Microbial Ecology 55, 293-310. 
Xuan, D., Guong, V., Rosling, A., Alström, S., Chai, B., Högberg, N., 2012. Different crop rotation systems as drivers of change in soil bacterial community structure and yield of rice, Oryza sativa. Biology and Fertility of Soils 48, 217-225.

Zak, D.R., Holmes, W.E., White, D.C., Peacock, A.D., Tilman, D., 2003. Plant diversity, soil microbial communities, and ecosystem function: Are there any links? Ecology 84, 20422050.

Zeglin, L., Stursova, M., Sinsabaugh, R., Collins, S., 2007. Microbial responses to nitrogen addition in three contrasting grassland ecosystems. Oecologia 154, 349-359.

Zhang, Y.-K., Schilling, K.E., 2006. Increasing streamflow and baseflow in Mississippi River since the 1940's: Effect of land use change. Journal of Hydrology 324, 412-422.

Zuur, A.F., Ieno, E.N., Elphick, C.S., 2010. A protocol for data exploration to avoid common statistical problems. Methods in Ecology and Evolution 1, 3-14. 

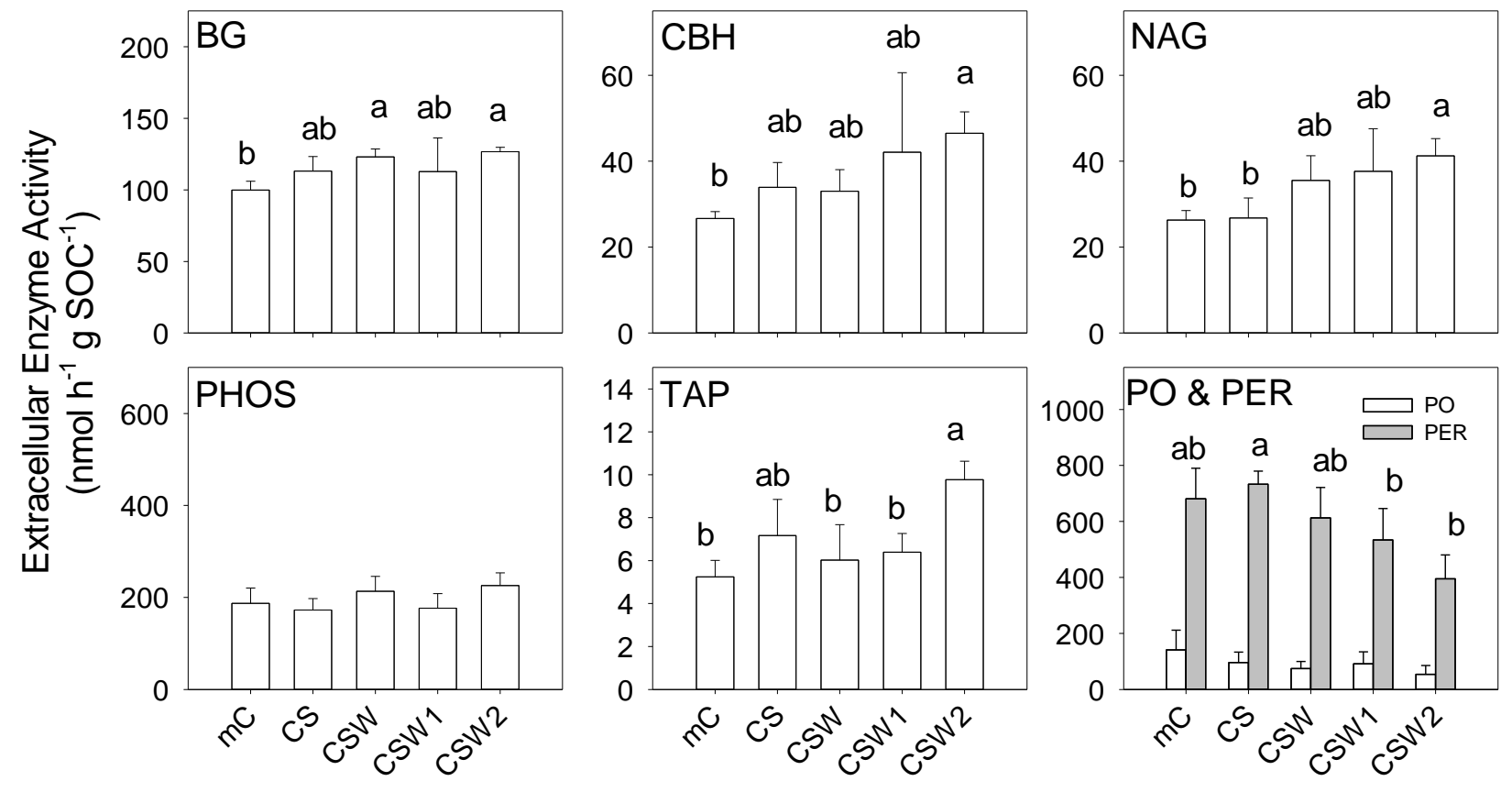

Treatment

Figure 1. 


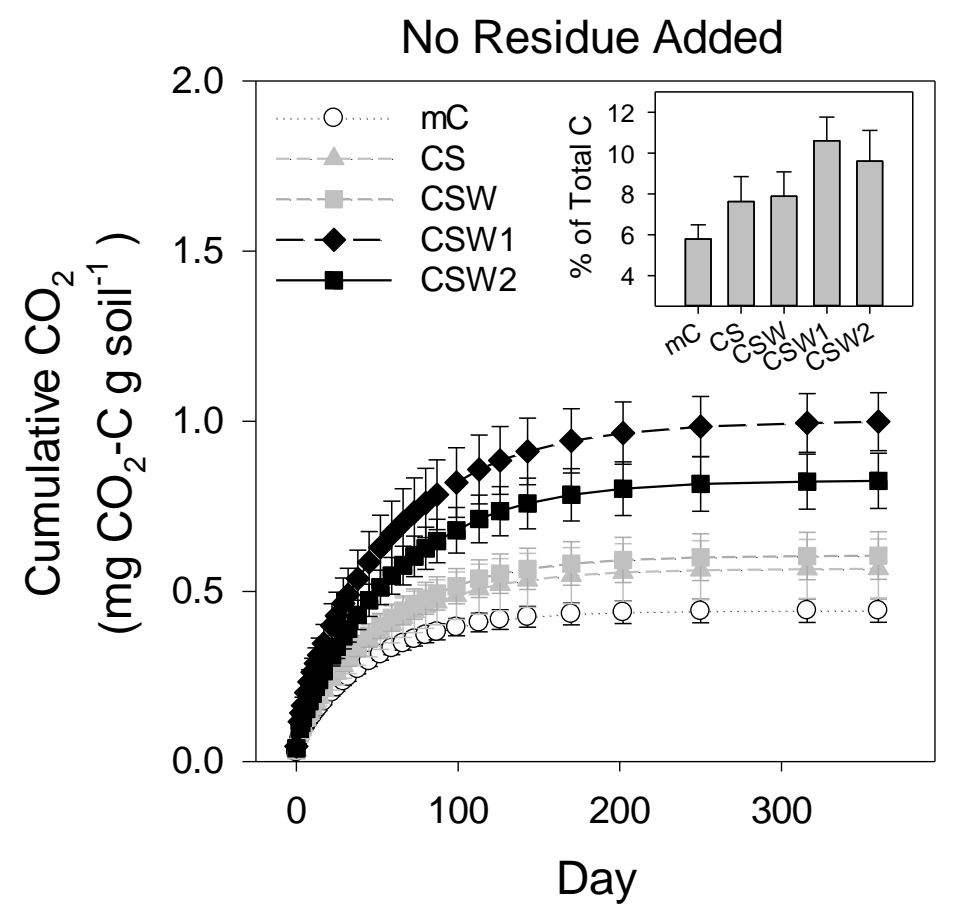

Figure 2. 

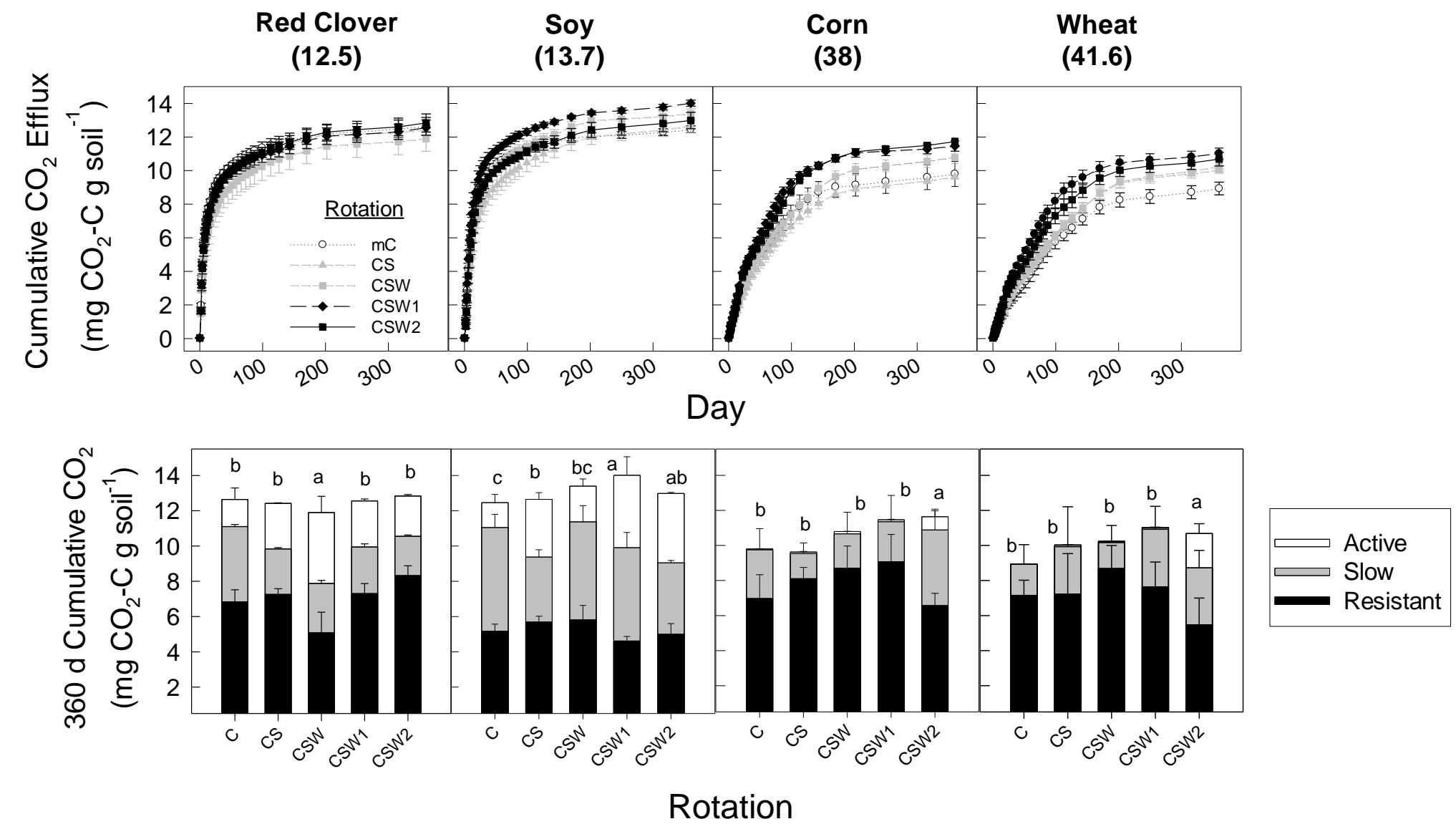

Figure 3. 


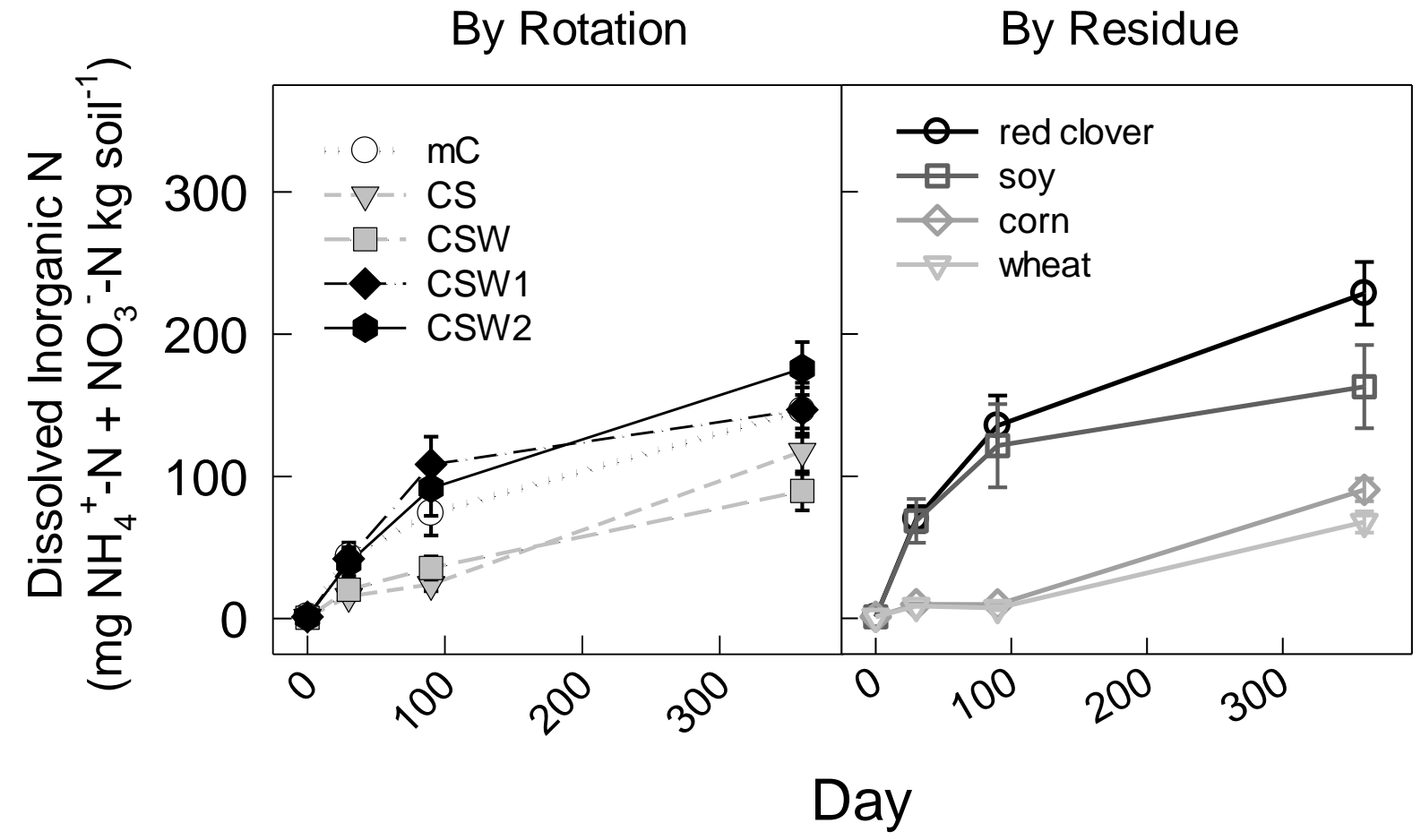

Figure 4. 


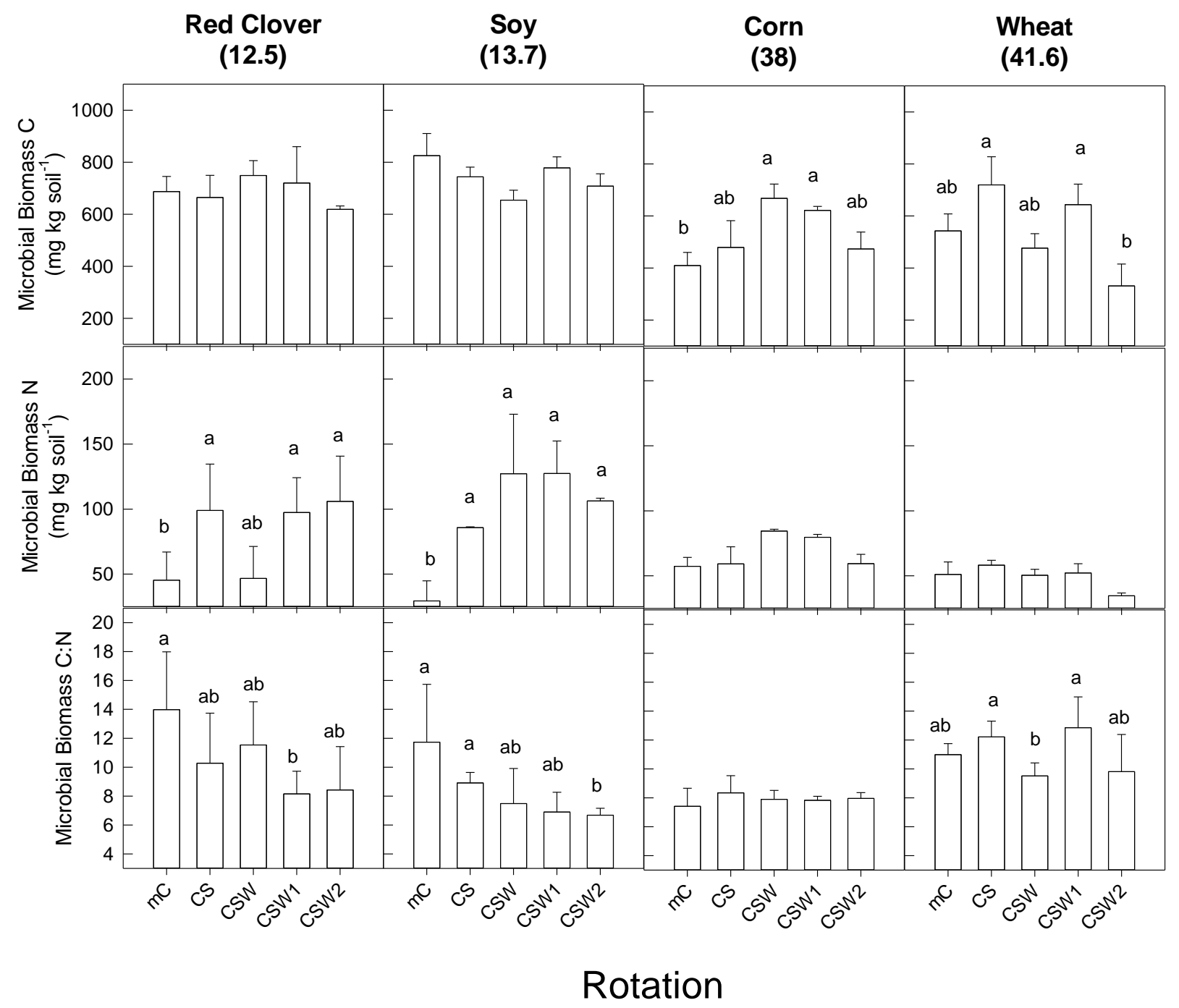

Figure 5. 

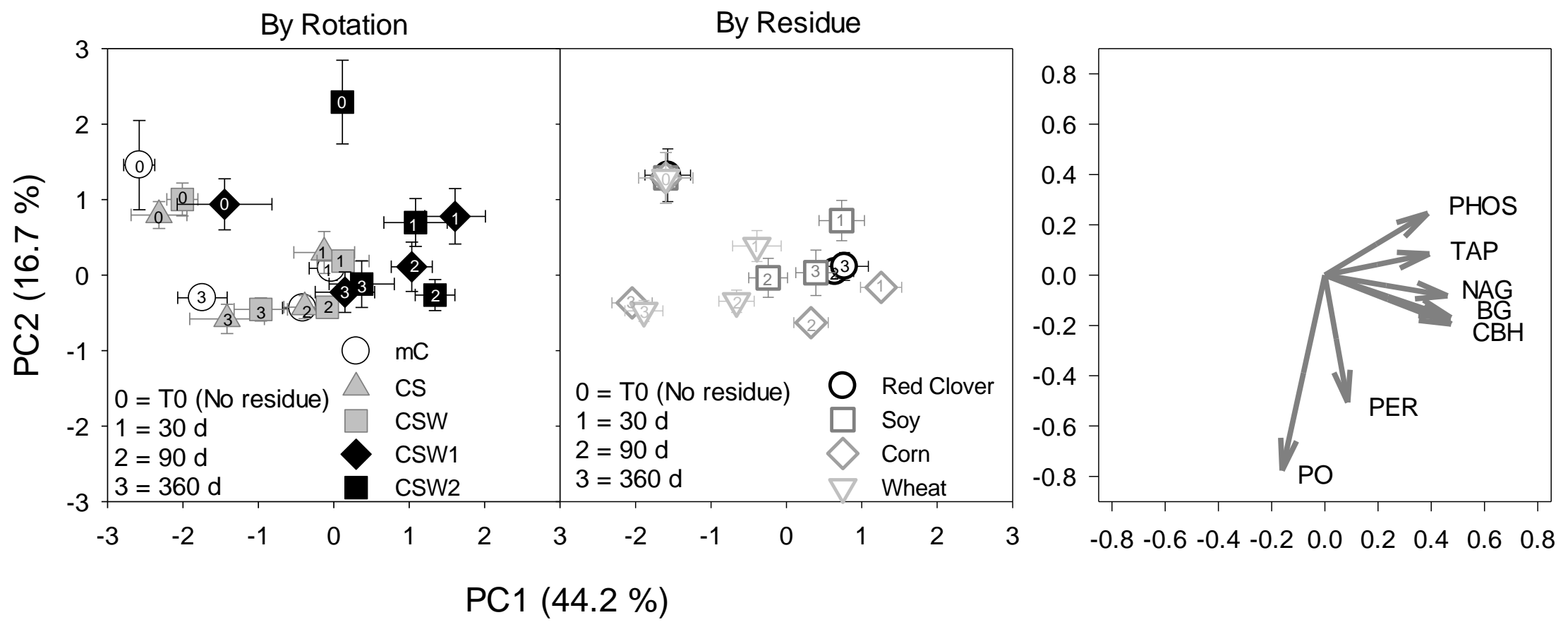

Figure 6. 


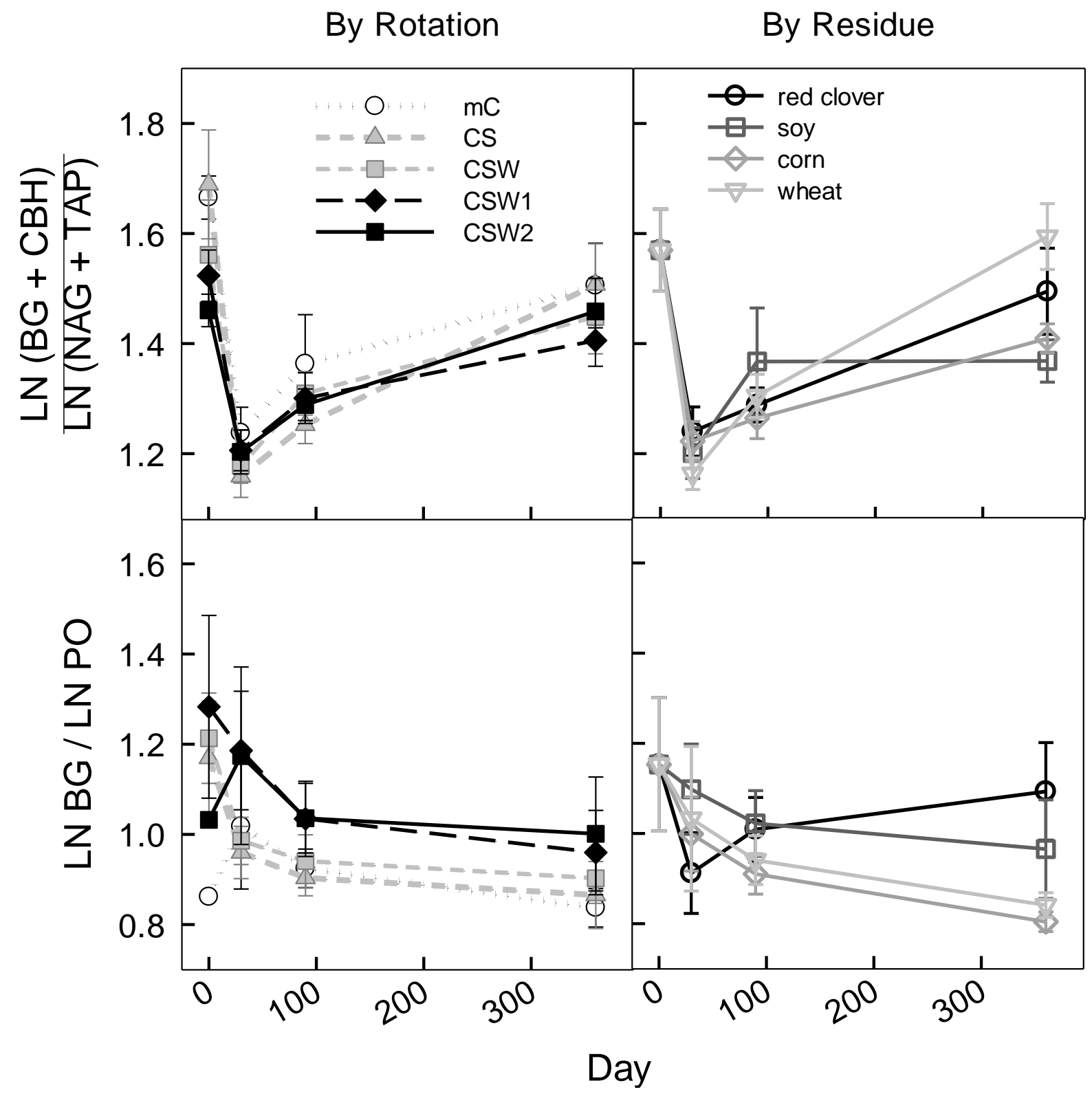

Figure 7. 
Table 1. Initial residue chemical composition

\begin{tabular}{|c|c|c|c|c|c|c|c|c|c|}
\hline Residue & $\mathrm{C}$ & $\mathrm{N}$ & $\mathrm{C}: \mathrm{N}$ & Lignin & Lipid & $\begin{array}{l}\text { Polysacch } \\
\text { aride } \\
\end{array}$ & N-Bearing & Protein & $\begin{array}{c}\text { Unknown } \\
\text { Origin } \$\end{array}$ \\
\hline \multicolumn{4}{|c|}{------- \% ------- } & \multirow{2}{*}{\multicolumn{6}{|c|}{ - Relative Abundance - - }} \\
\hline Corn & 46.3 & 1.2 & 38.0 & 0.409 & & & & & 0.211 \\
\hline Soy & 49.1 & 3.6 & 13.7 & 0.320 & 0.021 & 0.124 & 0.067 & 0.070 & 0.398 \\
\hline Wheat & 45.2 & 1.1 & 41.6 & 0.521 & 0.009 & 0.122 & 0.006 & 0.004 & 0.338 \\
\hline Red Clover & 46.5 & 3.7 & 12.5 & 0.177 & 0.068 & 0.123 & 0.046 & 0.125 & 0.461 \\
\hline
\end{tabular}

$\S$ These compounds have been identified, but are of variable origins. 
Table 2. Initial $\left(\mathrm{T}_{0}\right)$ soil biogeochemical parameters for the five crop rotation treatments.

\begin{tabular}{|c|c|c|c|c|c|}
\hline \multirow[b]{3}{*}{ Soil Parameter } & \multicolumn{5}{|l|}{ Crop Rotation } \\
\hline & $\begin{array}{l}\text { Monoculture } \\
\text { Corn }\end{array}$ & Corn-Soy & $\begin{array}{l}\text { Corn-Soy- } \\
\text { Wheat }\end{array}$ & $\begin{array}{l}\text { Corn-Soy- } \\
\text { Wheat } \\
+ \text { Red Clover } \\
\text { Cover Crop }\end{array}$ & $\begin{array}{c}\text { Corn-Soy- } \\
\text { Wheat } \\
+ \text { Red Clover \& } \\
\text { Rye Cover } \\
\text { Crops }\end{array}$ \\
\hline & $\mathrm{mC}$ & $\mathrm{CS}$ & CSW & CSW1 & CSW2 \\
\hline Carbon $\left(\mathrm{g} \mathrm{kg}^{-1}\right)$ & $7.9(0.8)$ & $7.6(0.7)$ & $7.8(0.3)$ & $9.6(0.8)$ & $8.9(0.9)$ \\
\hline Nitrogen $\left(\mathrm{g} \mathrm{kg}^{-1}\right)$ & $0.9(0.1)$ & $0.8(0.1)$ & $0.9(0.1)$ & $1.0(0.1)$ & $1.0(0.1)$ \\
\hline $\mathrm{C}: \mathrm{N}$ & $9.0(0.4)^{a b}$ & $9.6(0.6)^{a}$ & $8.7(0.7)^{b}$ & $9.5(0.3)^{\mathrm{a}}$ & $9.0(0.4)^{a b}$ \\
\hline $\mathrm{NH}_{4}-\mathrm{N}\left(\mathrm{mg} \mathrm{kg}^{-1}\right)$ & $0.18(0.04)$ & $0.29(0.13)$ & $0.35(0.07)$ & $0.48(0.16)$ & $0.36(0.15)$ \\
\hline $\mathrm{NO}_{3}-\mathrm{N}\left(\mathrm{mg} \mathrm{kg}^{-1}\right)$ & $1.46(0.63)$ & $0.97(0.36)$ & $0.61(0.13)$ & $1.3_{-}(0.32)$ & $0.91(0.24)$ \\
\hline Basal Respiration ( $\mu \mathrm{g} \mathrm{CO}_{2}-\mathrm{C}$ g soil $\left.^{-1} \mathrm{~d}^{-1}\right)$ & $22.02(4.37)^{b c}$ & $21.82(2.33)^{\mathrm{c}}$ & $24.05(1.9)^{b}$ & $33.12(2.67)^{\mathrm{a}}$ & $34.15(2.33)^{\mathrm{a}}$ \\
\hline Microbial biomass $\mathrm{C}\left(\mathrm{mg} \mathrm{kg}^{-1}\right)$ & $260(56)$ & $234(29)$ & $231(18)$ & $306(32)$ & $440(93)$ \\
\hline Microbial biomass $\mathrm{N}\left(\mathrm{mg} \mathrm{kg}^{-1}\right)$ & $17(1)^{b}$ & $22(3)^{a b}$ & $21(3)^{b}$ & $32(4)^{a}$ & $29(3)^{a}$ \\
\hline Microbial biomass C:N & $15(3)$ & $11(2)$ & $11(1)$ & $10(1)$ & $15(2)$ \\
\hline
\end{tabular}

Means and standard errors $(\mathrm{n}=4)$, significant treatment differences are shown in bold $(P<0.05)$ 
Table 3. ANOVA effects of Residue, Crop Rotation, and the interaction on all measured responses to residue addition.

\begin{tabular}{|c|c|c|c|c|c|c|c|c|}
\hline \multirow{3}{*}{ Parameter } & \multicolumn{6}{|c|}{ ANOVA Effect } & \multirow{3}{*}{$\begin{array}{l}\text { Post-hoc } \\
\text { Tests }\end{array}$} & \multirow{3}{*}{$\begin{array}{l}\text { Corresponding } \\
\text { Figure }\end{array}$} \\
\hline & \multicolumn{2}{|c|}{ Residue } & \multicolumn{2}{|c|}{ Crop Rotation } & \multicolumn{2}{|c|}{$\begin{array}{l}\text { Residue X } \\
\text { Rotation }\end{array}$} & & \\
\hline & $\mathrm{F}$ & $P$ value & $\mathrm{F}$ & $P$ value & $\mathrm{F}$ & $P$ value & & \\
\hline \multirow{3}{*}{$\begin{array}{l}\text { Instantaneous } \mathrm{CO}_{2}^{\S} \\
\text { Cumulative } \mathrm{CO}_{2}\end{array}$} & 62.79 & $=<0.001$ & 3.09 & 0.015 & 0.35 & 0.999 & $\mathrm{Rc}=\mathrm{S}>\mathrm{C}=\mathrm{W}$ & 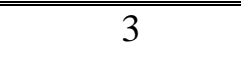 \\
\hline & & & & & & & $\mathrm{Rc}=\mathrm{S}>\mathrm{C}=\mathrm{W}$ & 3 \\
\hline & 58.36 & $<0.001$ & 6.95 & $<0.001$ & 1.58 & 0.125 & $\mathrm{CSW} 2=\mathrm{CSW} 1>\mathrm{CS}=\mathrm{mC}$ & \\
\hline Active & 63.42 & $<0.001$ & 6.25 & $<0.001$ & 6.97 & $<0.001$ & See Figure & 3 \\
\hline Slow & 3.92 & 0.013 & 0.4 & 0.804 & 0.72 & 0.727 & $\mathrm{~S}>\mathrm{Rc}=\mathrm{C}=\mathrm{W}$ & 3 \\
\hline Resistant & 11 & $<0.001$ & 0.64 & 0.634 & 0.48 & 0.918 & $\mathrm{C}=\mathrm{W}>\mathrm{Rc}=\mathrm{S}$ & 2 \\
\hline \multirow{2}{*}{$\begin{array}{l}\text { Dissolved inorganic } \mathrm{N}\left(\mathrm{NO}_{3}\right. \\
\left.+\mathrm{NH}_{4}^{+}\right)^{\S}\end{array}$} & & & & & & & $\mathrm{Rc}=\mathrm{S}>\mathrm{C}=\mathrm{W}$ & 4 \\
\hline & 4.39 & $<0.001$ & 3.67 & 0.006 & 0.73 & 0.999 & & \\
\hline Microbial biomass $\mathrm{C}$ at $30 \mathrm{~d}$ & 7.89 & $<0.001$ & 2.77 & 0.036 & 2.86 & 0.004 & See Figure & 5 \\
\hline Mcrobial biomass $\mathrm{N}$ at $30 \mathrm{~d}$ & 3.78 & 0.016 & 3.15 & 0.02 & 2.58 & 0.009 & See Figure & 5 \\
\hline MBC:MBN at $30 \mathrm{~d}$ & 4.39 & $<0.001$ & 7.29 & $<0.001$ & 3.52 & $<0.001$ & See Figure & 5 \\
\hline \multirow[t]{2}{*}{ All Extracellular-Enzymes ${ }^{¥}$} & & & & & & & $\mathrm{Rc}=\mathrm{S}>\mathrm{C}=\mathrm{W}$ & 6 \\
\hline & 8.48 & $<0.001$ & 13.25 & $<0.001$ & 0.0 .62 & 0.957 & $\mathrm{CSW} 2=\mathrm{CSW} 1>\mathrm{CSW}>\mathrm{mC}=\mathrm{CS}$ & \\
\hline $\mathrm{BG}+\mathrm{CBH} / \mathrm{NAG}+\mathrm{TAP}^{\S}$ & 0.75 & 0.525 & 2.38 & 0.052 & 0.22 & 0.997 & NA & 7 \\
\hline $\mathrm{BG} / \mathrm{PPO}^{\S}$ & 3.47 & 0.017 & 5.83 & $<0.001$ & 0.30 & 0.989 & $\mathrm{CSW} 2=\mathrm{CSW} 1>\mathrm{CSW}=\mathrm{mC}$ & 7 \\
\hline Hydrolase Efficiency & 11.20 & $<0.001$ & 5.64 & $<0.001$ & 1.12 & 0.362 & $\begin{array}{c}\mathrm{Rc}=\mathrm{S}>\mathrm{C}=\mathrm{W}, \\
\mathrm{CSW} 2=\mathrm{CSW} 1>\mathrm{mC}\end{array}$ & S3 \\
\hline Oxidoreductase Efficiency & 14.92 & $<0.001$ & 5.67 & $<0.001$ & 0.51 & 0.902 & $\begin{array}{c}\mathrm{Rc}>\mathrm{S}>\mathrm{C}=\mathrm{W}, \\
\mathrm{CSW} 2=\mathrm{CSW} 1>\mathrm{CSW}=\mathrm{CS}=\mathrm{mC}\end{array}$ & S3 \\
\hline
\end{tabular}

$\S$ Responses measured on multiple dates and were analyzed with repeated measures ANOVA

$¥$ A PERMANOVA on distance matrix from all enzymes.

Significant effects are highlighted with bold. The the Sidak-corrected $\alpha$ is $P \leq 0.005$. For post-hoc abbreviations see Tables 1 and 2 
Table 4. Pearson correlation coefficients (r) between chemical compounds and decomposition parameters $(n=75)$.

\begin{tabular}{|c|c|c|c|c|c|c|c|c|}
\hline $\begin{array}{l}\text { Respiration } \\
\text { Parameter }\end{array}$ & $\mathrm{C}$ & $\mathrm{N}$ & $\mathrm{C}: \mathrm{N}$ & Lignin & Lipid & Polysac. & N-bearing & Protein \\
\hline Active pool & $0.57^{\text {**** }}$ & $0.69^{* * *}$ & $-0.68^{\text {**** }}$ & $-0.51^{\text {*** }}$ & $0.43^{\text {**** }}$ & $-0.48^{\text {**** }}$ & $0.23^{* * * *}$ & $0.58^{* * *}$ \\
\hline Slow pool & $0.33^{* *}$ & ns & ns & ns & ns & ns & ns 0 & ns \\
\hline Resistant pool & $-0.44^{* * *}$ & $-0.58^{* * *}$ & $0.58^{* * *}$ & $0.47^{* * *}$ & $-0.41^{* * * *}$ & $0.37^{* * *}$ & ns & $-0.52^{* * *}$ \\
\hline Cumulative $\mathrm{CO}_{2}-\mathrm{C}$ & $0.68^{* * *}$ & $0.76^{* * *}$ & $-0.77^{* * *}$ & $-0.63^{* * *}$ & $0.48^{* * * *}$ & $-0.35^{\text {*** }}$ & $0.41^{* * *}$ & $0.65^{* * *}$ \\
\hline
\end{tabular}

$P$ values: $*<0.05, * *<0.01, * * *<0.001, \mathrm{~ns}=$ non-significant 